University of Pennsylvania Carey Law School

Penn Law: Legal Scholarship Repository

Faculty Scholarship at Penn Law

6-1-2005

\title{
Unilateral Refusals to License in the U.S.
}

\author{
Herbert J. Hovenkamp \\ University of Pennsylvania Carey Law School \\ Mark D. Janis \\ Indiana University Maurer School of Law \\ Mark A. Lemley \\ Stanford Law School
}

Follow this and additional works at: https://scholarship.law.upenn.edu/faculty_scholarship

Part of the Antitrust and Trade Regulation Commons, Economic Policy Commons, Intellectual Property Law Commons, Law and Economics Commons, Policy Design, Analysis, and Evaluation

Commons, Science and Technology Policy Commons, and the Technology and Innovation Commons

\section{Repository Citation}

Hovenkamp, Herbert J.; Janis, Mark D.; and Lemley, Mark A., "Unilateral Refusals to License in the U.S." (2005). Faculty Scholarship at Penn Law. 1920.

https://scholarship.law.upenn.edu/faculty_scholarship/1920

This Article is brought to you for free and open access by Penn Law: Legal Scholarship Repository. It has been accepted for inclusion in Faculty Scholarship at Penn Law by an authorized administrator of Penn Law: Legal Scholarship Repository. For more information, please contact PennlawIR@law.upenn.edu. 


\title{
2. Unilateral Refusals to License in the $\mathrm{US}^{1}$
}

\author{
Herbert Hovenkamp, Mark D. Janis and \\ Mark A. Lemley
}

\section{INTRODUCTION AND BACKGROUND}

Most antitrust claims relating to intellectual property involve challenges to agreements, licensing practices or affirmative conduct involving the use or disposition of the intellectual property rights or the products they cover. But sometimes an antitrust claim centers on an intellectual property owner's refusal to use or license an intellectual property right, perhaps coupled with efforts to enforce the intellectual property right against infringers. ${ }^{2}$ The allegation may be that the intellectual property right is so essential to competition that it must be licensed across the board, or that a refusal to license it to one particular party was discriminatory, or that in context a refusal to license helped a monopolist to acquire or maintain market power.

Claims based on a unilateral refusal to license - the subject of this chapter - present important issues at the center of the tension between antitrust and intellectual property. The antitrust and intellectual property laws are not necessarily in conflict. For the most part they serve complementary goals, though each must limit the scope of the other. Unilateral refusal to license cases, however, cut to the heart of the intellectual property owner's right to exclude others from practicing the intellectual property. ${ }^{3}$ As such, efforts to invoke antitrust law in this context deserve special scrutiny.

Section II reviews the basic principles relating to unilateral refusals to license intellectual property rights. Section III discusses in detail the various sets of circumstances in which antitrust plaintiffs argue for exceptions to those basic rules. Section IV distinguishes unilateral from concerted and conditional refusals to deal. 


\section{BASIC PRINCIPLE: NO GENERAL DUTY TO LICENSE}

\section{A. No Duty to Use IP At AlI ${ }^{4}$}

The starting point for understanding the unilateral refusal to license cases is the fundamental principle that an intellectual property owner has no obligation to use its right at all. In patent cases, this principle was established in the 1908 Supreme Court decision of Continental Paper Bag v. Eastern Paper Bag. ${ }^{5}$ In that case, Eastern owned a patent describing a machine for making 'self-opening' paper bags. Eastern never used the machine described in the patent, and did not license it to others. When it sued Continental for infringing the patent, Continental defended on the ground that it would be inequitable to enforce the patent because Eastern wasn't using the patented machine, and was merely trying to use the patent to suppress competition. The district court found that 'complainant stands in the common class of manufacturers who accumulate patents merely for the purpose of protecting their general industries and shutting out competitors. ${ }^{6}$ While the Supreme Court accepted this explanation, it nonetheless reversed. The court noted that 'such exclusion may be said to have been of the very essence of the right conferred by the patent, as it is the privilege of any owner of property to use or not use it, without question of motive.'7

Congress has since codified the patent owner's right to refuse to use the patent. Section 271(d)(4) provides that a patent owner cannot be deemed guilty of misuse by virtue of its refusal to use or license the patent. ${ }^{8}$

Copyright and trade secret laws similarly condone non-use and nondisclosure of the rights in question. Indeed, in trade secrecy the effective concealment of the secret is a prerequisite to protection, and courts discuss licensing in terms of whether licensing is inconsistent with continued protection. ${ }^{9}$ Compelled licensing would therefore be inconsistent with trade secret protection. Copyright owners have since 1976 been entitled to protect both published and unpublished works, and indeed copyright protection is somewhat more powerful for unpublished works due to the copyright owner's stronger interest in preventing use of the work. ${ }^{10}$ Trademark law, by contrast, does require use in commerce as a prerequisite for protection. But the use in question must be made by (or inure to the benefit of) the trademark owner itself; trademark law strictly regulates efforts to license marks to third parties. 


\section{B. Right to Enforce IP; No General Compulsory Licensing}

Concomitant with the general right to refuse to use an intellectual property right is the right to enforce that intellectual property right against infringing use by others. A 'right' to refrain from using intellectual property would be a hollow thing indeed if the intellectual property owner could not prevent others from infringing the right. Since intellectual property laws merely confer the right to exclude others from doing certain things, they can only be enforced by resort to the courts. As the Court put it in Continental Paper Bag, 'the right can only retain its attribute of exclusiveness by a prevention of its violation. Anything but prevention takes away the privilege which the law confers upon the patentee. ${ }^{11}$ Copyright decisions have similarly confirmed that copyright owners may refuse to license their rights, and may enforce those rights by lawsuit. ${ }^{12}$

It is periodically suggested, however, that even if an intellectual property owner can enforce an unused right, the enforcement of that right ought to be limited to a right to recover damages rather than an entitlement to injunctive relief. Such an approach would effectively constitute a judicially-created compulsory licensing scheme. Instead of a property rule, to which intellectual property owners are normally entitled, ${ }^{13}$ the court would be substituting a liability rule. A few courts have refused to grant injunctions in the patent context where inventions related to public health or safety are at issue. For example, in Milwaukee v. Activated Sludge,${ }^{14}$ the patentee owned a patent for the treatment of raw sewage. It successfully sued a sewage treatment plant for infringement. The court refused to grant an injunction, however, because doing so would force the public to put up with untreated sewage. The patentee was instead relegated to a damages remedy. ${ }^{15}$ The Supreme Court has also suggested in the copyright context that injunctive relief may not always be appropriate against infringers who have nonetheless contributed substantial new material to an infringing work. ${ }^{16}$

These cases are small exceptions to a broad rule, however. The intellectual property laws contain no general provision for compulsory working or licensing of intellectual property rights. While courts have occasionally refused to enjoin infringing uses where some sort of overriding public interest was at stake, they have generally done so on the basis of intellectual property rather than antitrust principles. Antitrust law does not itself impose an obligation to use or license intellectual property rights, such that a refusal to use or license the right would violate the antitrust laws. Further, such an obligation would - unlike the vast majority of the antitrust rules we discuss in this text - conflict directly with the rights granted to an intellectual property owner by the intellectual property laws. Thus, as a general rule there is no antitrust obligation either to use or license a patent. ${ }^{17}$ 


\section{Right to Refuse to Deal with Specific Customers}

A variant of the argument that an intellectual property owner may be compelled to use or license its right is the argument that the intellectual property owner cannot discriminate in the grant of licenses once it does make them available. This is a common species of antitrust complaint; plaintiffs frequently argue that they have been unfairly disadvantaged because their competitor got a license and they didn't, or because their competitor got a license on more favorable terms. In this section, we deal only with claims of unilateral refusals to license. ${ }^{18}$

Antitrust law is generally hostile to such claims, even where intellectual property rights are not at issue. The Court's repeated invocation of the rule that the antitrust laws 'protect competition, not competitors" ${ }^{19}$ seems applicable here. Thus, in Olympia Equip. Leasing v. Western Union Telegraph ${ }^{20}$ Judge Posner noted that it is clear that a firm with lawful monopoly power has no general duty to help its competitors, whether by holding a price umbrella over their heads or by otherwise pulling its competitive punches. ${ }^{21}$ An antitrust violation is even less likely where the intellectual property owner does not compete directly with the disfavored licensee; absent some showing of monopoly leveraging it is not clear what incentive the intellectual property owner would have to try to eliminate competition in the downstream market.

Where a license has been granted and is later revoked, some courts have seen the issue differently, suggesting some sort of legal obligation to continue an existing business relationship. ${ }^{22}$ Even then, imposing such an obligation is unusual. Olympia Leasing itself rejected an obligation to continue dealing with a competitor. ${ }^{23}$ In the intellectual property context, Miller Insituform v. Insituform of North America held that an exclusive patent licensee did not violate the antitrust laws when it terminated a sublicense to the plaintiff and instead entered the market itself. $^{24}$ The court held that by terminating the license the exclusive licensee 'merely exercised his power to exclude others from using the Insituform process, as was its right' under the patent laws. ${ }^{25}$

Where intellectual property licenses are at issue, there are even stronger policy reasons than normal not to impose a nondiscrimination obligation in the choice of licensees. The purpose of intellectual property rights is to encourage innovation by granting their owner a reward better than it could obtain in a competitive market. Sometimes that reward is maximized if the intellectual property owner uses the right itself and does not license it to others. But it may be rational for intellectual property owners to license their rights to others for a number of reasons. They may be ill-equipped to make the protected product; they may want a revenue stream without having to invest in producing and selling the product; they may wish to reserve one 
geographic or product market to themselves, while allowing others to exploit the intellectual property right elsewhere; or they may simply feel that broad dissemination of their product will redound to their benefit (for example, because there is value in having their product become an industry standard).

Economic theory encourages licensing, because it allows the market to transfer the intellectual property right to the most productive user of that right. ${ }^{26}$ But efficient licenses will often be exclusive in nature, or at least restricted in geographic scope, field of use, or extent or duration of use. If an intellectual property owner who once licenses a right is thereafter compelled to make licenses available to all comers on substantially equal terms, the likely effect will be to discourage licensing altogether. Certainly the effect would be to prohibit exclusive licensing, which is often the most efficient means of extracting value from an intellectual property right. ${ }^{27}$

As a result, some courts have proposed a general rule: 'A patent holder who lawfully acquires a patent cannot be held liable under Section 2 of the Sherman Act for maintaining the monopoly power he lawfully acquired by refusing to license the patent to others. ${ }^{, 28}$ This proposed per se rule of legality is somewhat stronger than the rule in non-intellectual property cases. Outside the intellectual property context, unilateral refusals to deal with specific customers on nondiscriminatory terms are generally illegal only if the subject of the refusal is an 'essential facility'. We discuss the application of the essential facilities doctrine to intellectual property, and the more general question of whether a unilateral refusal to license intellectual property can ever violate the antitrust laws, in more detail below. ${ }^{29}$

\section{Policy Basis; Practical Problems with Contrary Rule}

The fundamental basis for permitting most unilateral refusals to use or license an intellectual property right should be clear from the preceding sections. Unlike the Walker Process or sham litigation cases, ${ }^{30}$ the cases we are considering involve a valid right infringed by others. Intellectual property law generally permits owners to enforce their rights by means of an injunction, and does not compel them to use or license those rights to others. For antitrust law to reach a contrary conclusion would require it to make illegal precisely the same conduct that the intellectual property laws explicitly authorize. Doing so would significantly reduce the innovation incentive intellectual property provides, not only to those who refuse to use the invention at all, but also to those who wish to license their rights only under certain conditions.

The practical problems with a compulsory working or licensing scheme further counsel against such a rule. In the first place, it is worth noting that many - perhaps a majority - of patented inventions are simply impractical to use. The invention may cost too much to implement, or the market may not 
exist for it. A rule that required all patents to be offered for license would simply result in wasted expenditures in many cases. It would also prevent a patentee from choosing to exploit only one of many competitive technologies it has developed, and therefore might have the effect of punishing innovators who work along parallel lines. ${ }^{31}$ Alternatively, should antitrust law seek to compel the licensing only of truly valuable technologies, it would be put to the nearly impossible task of defining and then determining which intellectual property rights should fit into that category. ${ }^{32}$ Similarly, if the obligation is that the patentee work its invention, someone will have to determine whether the patentee is satisfying that requirement by evaluating the patentee's products, by resolving disputes over uses in different sub-fields, and so on.

Even more problematic is that a court that imposed a duty to license must engage in price regulation of the license. A rule that requires licensing but lets the licensor set the price is easily evaded by the licensor setting an exorbitant royalty. So any scheme that requires the intellectual property owner to license its rights must also include some (presumably judicial, but perhaps administrative) mechanism for pricing those rights. Such a system should in turn probably have continuing oversight over the rates charged, since their reasonableness may change over time. ${ }^{33}$ The specter of ongoing judicial intervention in product pricing goes a long way towards explaining why antitrust law avoids compelling licenses altogether in most circumstances.

\section{CIRCUMSTANCES ALLEGED TO GIVE RISE TO A DUTY TO LICENSE}

As noted in the previous section, there is no general duty under either the intellectual property or antitrust laws to use or license an intellectual property right. Most of the cases that are litigated in this area therefore allege specific factual circumstances that might give rise to an exception to this general rule. Generally speaking, exceptions to the rule are rare, and normally involve circumstances in which an intellectual property owner has sought to expand the scope of its right beyond what the intellectual property laws grant it. In this section, we consider the claims most commonly made for exceptional duties to license.

\section{A. Market Power Prerequisite}

At the outset, it is worth emphasizing that we are dealing in this chapter only with purely unilateral refusals to deal. ${ }^{34}$ Unilateral conduct is actionable if at 
all under Section 2 of the Sherman Act, where it helps a party to acquire or maintain monopoly power. Thus, in each of the factual circumstances discussed here, proof that the defendant has or is likely to obtain monopoly power is a necessary prerequisite to an antitrust claim. In the absence of monopoly power, there is no set of circumstances in which a truly unilateral refusal to license can violate the antitrust laws. ${ }^{35}$ Even Section 2 claims based on conduct also addressed in other antitrust statutes, such as tying or exclusive dealing, require proof of market power if they are brought as challenges to unilateral conduct under Section 2.

Similarly, because unilateral refusals to deal will be illegal if at all under Section 2 of the Sherman Act, the other attributes of the rule of reason must be satisfied. In particular, antitrust defendants should have the opportunity to demonstrate procompetitive justifications for their conduct. Proof that a unilateral refusal to license was on net pro- rather than anticompetitive should dispose of a claim under the rule of reason. ${ }^{36}$

\section{B. Invalid Intellectual Property Rights}

It is also important to emphasize that this chapter deals only with refusals to license valid intellectual property rights. Similarly, to the extent it discusses liability for bringing an infringement lawsuit, we deal here only with situations where the infringement claim is supported by probable cause. Many Section 2 claims have at their heart the argument that the intellectual property in question was obtained by fraud, is invalid, or is not infringed, and the intellectual property owner is knowingly enforcing this invalid right in order to obtain a competitive advantage. ${ }^{37}$

\section{Essential Facilities Doctrine ${ }^{38}$}

\section{Background; criticism of doctrine}

One possible antitrust approach to refusals to use or license an intellectual property right does not focus on conduct at all. Instead, the argument is that certain monopolies inherently give rise to a duty to deal fairly with all comers. Courts sometimes hold that a monopolist has a duty to deal with competitors, or at least to continue a relationship once it has begun. Under this doctrine, the monopoly owner of an 'essential facility' for competition may be forced to give access to that facility to competitors on reasonable and nondiscriminatory terms. The essential facilities doctrine is unique in that a monopolist's status (as the owner of the facility and a competitor in the market that relies on the facility) rather than any affirmative conduct determines liability. ${ }^{39}$ 
The essential facilities doctrine grew out of a number of cases in which a vertically integrated company (or a group of them) had exclusive control over some facility, and used that control to gain an advantage over competitors in an adjacent or downstream market. Most of the canonical cases have this basic structure. Thus, in Terminal Railroad, a group of railroads jointly owned a key bridge over the Mississippi River and accompanying rail yard, and refused to give competing railroads use of the facilities. ${ }^{40}$ In Otter Tail, the public utility that owned all the transmission lines into a municipality refused to allow the municipality to 'wheel' power over those lines from outside plants, because the utility itself wanted to provide power to the municipality. ${ }^{41}$ And in $M C I$ v. $A T \& T$, the pre-breakup Bell System refused to permit MCI to connect its long distance calls to the Bell System's local phone exchanges. ${ }^{42}$ In each of these cases, the defendant owned a facility that could not feasibly be duplicated, and also participated in a competitive downstream market that required access to the facility. By denying access to the facility, the defendant either eliminated its downstream competitors or imposed significant costs on them. ${ }^{43}$

In $M C I$, the court set out a four-part test for an essential facilities claim:

1. control of the essential facility by a monopolist;

2. a competitor's inability practically or reasonably to duplicate the essential facility;

3. the denial of the use of the facility to a competitor; and

4. the feasibility of providing the facility. ${ }^{44}$

If such a claim is made out, the defendant will be obligated to provide access to the facility on reasonable and nondiscriminatory terms.

Under this test, the defendant must be a monopolist, and the facility must be 'essential' in the sense that the competitor needs access to it in order to compete. An essential facility will therefore normally be an input into the competitive market - some component that must be used in providing the competitive product or service. The need must be substantial, however inconvenience or cost increase resulting from unavailability should not suffice. ${ }^{45}$ The court's test also offers a defense of legitimate business justification, by permitting the defendant to show that it wasn't feasible to provide access to the facility. The 'reasonable and nondiscriminatory terms' language also limits the defendant's obligation in circumstances where particular plaintiffs cannot afford to pay, aren't willing to pay a reasonable price, or the like. ${ }^{46}$

While the court doesn't discuss it directly, it seems important to add that withholding an essential facility is illegal only if it has the effect of foreclosing competition in the downstream market, and therefore of helping 
the defendant to acquire or maintain a monopoly in that market. Otter Tail and MCI both had such a characteristic; arguably so did Aspen. ${ }^{47}$ In the absence of such a market effect, condemning a truly unilateral refusal to deal could open the door to all sorts of claims in which competition is not really at stake.

The essential facilities doctrine as a whole has come in for serious criticism. In its most recent treatment of the issue, the Supreme Court engaged in a bit of revisionist history, distancing itself from the doctrine and claiming that the Court had 'never recognized such a doctrine' ${ }^{48}$ Many prominent antitrust scholars have argued that the doctrine should be abolished outright. ${ }^{49}$ Others who favor the continued existence of the doctrine nonetheless concede that it is properly applied only in rare cases. ${ }^{50}$

\section{Intellectual property itself as essential facility}

Regardless of the merits of the essential facilities doctrine in general, its application to intellectual property cases is particularly problematic. Generally speaking an intellectual property owner has the right unilaterally to decide not to use or license its intellectual property. Imposing a duty to deal in some cases threatens to undermine this basic principle. As a result, we are aware of no case in which a US court has held that an intellectual property right was itself an essential facility that must be licensed on reasonable and nondiscriminatory terms. ${ }^{51}$

Two recent cases involve claims that intellectual property rights are essential facilities. In Intergraph Corp. v. Intel Corp. ${ }^{52}$ Intergraph sued Intel after Intel cut off its supply of microprocessors and proprietary information. Intergraph, which makes computer workstations using Intel architecture and Intel microprocessors, had threatened to sue Intel's customers for violating Intergraph patents, an act that triggered Intel's obligation to defend those customers. In response, Intel threatened to stop supplying Intergraph with chips or technical assistance unless Intergraph dropped its patent suit. When Intergraph ultimately sued Intel for patent infringement, it also made a variety of antitrust claims based on Intel's efforts to cut off the flow of technology to Intergraph. ${ }^{53}$

Among Intergraph's claims was an essential facilities argument. Intergraph argued that access to Intel's chips and technical know-how was vital to its business, and that Intel should be compelled to license its patents and trade secrets to Intergraph on reasonable and nondiscriminatory terms. The district court granted a preliminary injunction, finding that Intel's intellectual property rights related to its chip architecture was indeed an essential facility. ${ }^{54}$

The Federal Circuit reversed. ${ }^{55}$ On the essential facilities issue, the court reviewed the doctrine in detail and concluded that an essential facilities claim 
could not be made out unless the owner of the essential facility and the antitrust plaintiff competed in a market that required access to the facility. The court noted that the gravamen of an essential facilities claim has always been an attempt to use control of such a facility to gain an unfair competitive advantage in a downstream market in which the defendant and the plaintiff competed.$^{56}$ Because it held that Intergraph and Intel did not compete at all, the court concluded that Intergraph could not possibly make out an essential facilities claim. ${ }^{57}$

In Aldridge v. Microsoft Corp. ${ }^{58}$ the plaintiff was the seller of a disk caching program. When Microsoft preempted the plaintiff's market by including a competing disk caching function in the new version of its computer operating system, Aldridge sued, claiming that Microsoft had violated the antitrust laws. Aldridge argued that Windows 95 was an essential facility because if a program didn't run on Windows 95 , it was effectively unavailable to the overwhelming majority of users. ${ }^{59}$ Aldridge argued that its disk caching program, which had run on previous Microsoft operating systems, was disabled on Windows 95, and that as a result it was denied access to the facility by Microsoft, a company itself entering the disk caching business. The court restated the four-part test discussed in $M C I$, adding the requirement that 'the defendant has the type of control over the facility that is forbidden by the Sherman Act. ${ }^{60}$ The court held that Aldridge failed to meet several elements of the test. First, it held that the facility in question was not essential, a conclusion we discuss below. Second, it noted that the essential facilities doctrine has only been applied in cases where there is either a natural monopoly or a government-supported one. ${ }^{61}$ Microsoft's operating system was neither. ${ }^{62}$

In both Intergraph and Aldridge, the plaintiff's claims seemed to founder primarily on the fact that they were seeking to continue privileged access that they had received in the past, not a level of access that could be provided to everyone. Thus, while the continuation of this access was 'essential' to the plaintiff's business model in both cases, it did not qualify as an essential facility under the antitrust laws. As the court in Aldridge put it, 'a facility is essential under the antitrust laws only when it is vital to both the plaintiff's individual competitive viability and the viability of the market in general. ${ }^{.63}$ The court rejected the idea that even monopolists must pre-disclose information about their own products so that others can build compatible products. $^{64}$

In neither case did the court expressly hold that a facility protected by intellectual property rights could never be essential. In Intergraph, the Federal Circuit didn't focus on the intellectual property aspects of the case at all, even though Intel's provision of information included both its patented architecture and trade secrets. Aldridge doesn't discuss the issue directly, but 
does focus on the problem of innovation. In that case, Microsoft's exclusion of Aldridge's disk caching program occurred when Microsoft solved problems in its previous operating systems that Aldridge had been correcting. The court warned against punishing Microsoft for improving its product: 'Such a result would inhibit, not promote, competition in the market. The antitrust laws do not require a competitor to maintain archaic or outdated technology; even monopolists may improve their products. ${ }^{65}$ Similarly, in rejecting Aldridge's pre-disclosure argument, the court noted that Microsoft 'could lawfully decline to reveal advances in technology. ${ }^{, 66}$ While neither passage speaks to intellectual property rights directly, the court clearly seems concerned to preserve monopolists' incentives to innovate.

One decision suggesting that intellectual property may constitute an essential facility is the district court's decision in BellSouth Advertising v. Donnelley Information. ${ }^{67}$ In that case, BellSouth sued Donnelley for copyright infringement after Donnelley copied the organization of its telephone 'yellow pages'. Donnelley counterclaimed on the grounds that the Bell yellow pages were an essential facility to which it was entitled to access. The district court found that Donnelley did infringe BellSouth's copyright. ${ }^{68}$ Nonetheless, it proceeded to hold that there was a genuine issue of fact for trial on the question of whether BellSouth's copyrighted telephone directory was an essential facility to which it had to provide access. The court addressed the fact that the 'facility' in question was information:

Although the doctrine of essential facilities has been applied predominantly to tangible assets, there is no reason why it could not apply, as in this case, to information wrongfully withheld. The effect in both situations is the same: a party is prevented from sharing something essential to compete. ${ }^{69}$

The court did not discuss the fact that the directory was copyrighted in the context of an essential facilities claim. However, since the court had just held that the directory was copyrighted, it necessarily must have concluded that a copyrighted work could be an essential facility. Indeed, Aldridge cites BellSouth for the proposition that the telephone directory can be an essential facility because it is copyrighted, since copyright law gives BellSouth effective control over access to the facility. ${ }^{70}$

While these cases present the issue, none of the courts directly address the question of whether an intellectual property right itself - or products protected by an intellectual property right - can constitute an essential facility. We believe the better view is that an intellectual property right itself cannot constitute an essential facility, and that the doctrine should not be applied to cases that seek access to an intellectual property right in any but the most unusual of circumstances. ${ }^{71}$ 
The essential facilities doctrine itself is a rare and controversial departure from the general principle that even monopolists do not violate the antitrust laws unless they engage in anticompetitive conduct that helps them acquire or maintain a monopoly. The essential facilities doctrine has been successfully applied primarily in cases in which the facility in question is a natural monopoly, often regulated, and the owner of that facility uses its monopoly to suppress competition in a downstream market. ${ }^{72}$ Intellectual property, as we have seen, is rarely coextensive with a monopoly at all, much less a regulated or natural monopoly. Further, to the extent that intellectual property rights themselves are thought to create the barriers to competition necessary to make a facility essential, that measure of market control is part and parcel of the incentives conferred by the intellectual property laws themselves. As the Supreme Court explained in the context of a telecommunications company, 'compelling ... firms to share the source of their advantage is in some tension with the underlying purpose of antitrust law, since it may lessen the incentive for the monopolist, the rival, or both to invest in ... economically beneficial facilities. ${ }^{73}$ The risk is even greater where intellectual property rights are at stake.

There are practical problems with such a requirement as well. Almost invariably, essential facilities claims involving intellectual property turn out to be claims demanding a continuation of privileged access to a monopolist's technology by a competitor who has built a market in goods or services complementary to or downstream from that particular technology. Thus, Intergraph wants continued access to Intel's proprietary information, and Aldridge wants pre-release access to Microsoft's applications program interfaces. $^{74}$ To grant such access conflicts directly with the rules of intellectual property law, which as we have seen permit the intellectual property owner to refuse to license or use its rights at all. ${ }^{75}$ It requires the courts to determine both a reasonable price for the license and fair conditions for access by others, and to supervise that access on an ongoing basis. ${ }^{76}$ And it does so without the normal prerequisite: proof that the intellectual property owner has sought to expand the scope of the right beyond what the intellectual property laws permit.

Where an essential facilities claim is premised solely on ownership of an intellectual property right (the 'essential' facility) by a vertically integrated monopolist, therefore, we believe the purposes of antitrust law are best served by denying such a claim outright. ${ }^{77}$ As the court in In re Microsoft Corp. Antitrust Litigation warned, 'to require one company to provide its intellectual property to a competitor would significantly chill innovation'. ${ }^{78}$ In the next section, we consider some limitations on this general principle. 


\section{Intellectual property as incidental to essential facilities claim}

Our conclusion in the prior section that intellectual property itself should not constitute an essential facility does not resolve all of the issues, however. Obviously, a monopolist can voluntarily agree to license its intellectual property rights on reasonable and nondiscriminatory terms, even though the law does not compel it to do so. For example, intellectual property owners that are members of standard-setting organizations often commit to licensing intellectual property rights covering a standard set by the group to anyone who wants to use the standard. Once it has agreed to do so, a monopolist is bound to license its intellectual property right just as any other party would be. But it is contract rather than antitrust law that compels the company in this case.

A slightly different case, but one that still falls within the rubric of voluntary agreements to license, involves nondiscriminatory licensing as a condition of merger approval. An example is the license imposed by consent decree in In re Silicon Graphics, Inc. ${ }^{79}$ The Federal Trade Commission challenged Silicon Graphics' purchase of software makers Alias and Wavefront, arguing that it constituted both horizontal integration (Alias and Wavefront were competitors) and vertical integration with Silicon Graphics, the largest maker of workstations running entertainment graphics software. The Commission entered into a consent decree with Silicon Graphics that compelled SGI to license the Alias and Wavefront software to all comers on nondiscriminatory terms ${ }^{80}$ While Silicon Graphics was 'compelled' in some sense to license its intellectual property rights, the FTC's action doesn't raise essential facility concerns. So long as the FTC had legitimate grounds to challenge the merger for other antitrust reasons, it was free to settle its challenge by imposing reasonable conditions to which Silicon Graphics agreed. ${ }^{8}$

A third set of cases that should escape the rule of per se legality we suggested above has to do with the proper scope of the intellectual property right in question. The analysis in the preceding section presumes both that the intellectual property right in question is valid, and that what a plaintiff seeks to compel is in fact within the legitimate scope of the intellectual property right. If that is not the case, the intellectual property owner deserves no special protection from the normal operation of the essential facilities doctrine. Certainly an invalid intellectual property right should offer no immunity, though it is also hard to imagine a set of circumstances in which access to such a right would have to be compelled. A more plausible situation involves an antitrust claim of access to information that intellectual property law does not protect - the ideas in a copyrighted work, for example. ${ }^{82}$ In such a case, the essential facilities claim should be approached as if the intellectual property right didn't exist - that is, intellectual property will not confer any 
immunity, but a plaintiff must still prove all the elements necessary for an essential facilities claim. Thus, we would disagree with those courts that have found a legitimate business justification in the prevention of 'free riding' on the defendant's information in the absence of any intellectual property right in that information. ${ }^{83}$ In the absence of intellectual property protection, 'free riding' on facts and ideas is affirmatively encouraged by intellectual property law. A desire to mimic intellectual property protection where the law has provided none should not translate into a defense to an otherwise proper antitrust claim.

The most difficult conceptual issue concerns intellectual property rights that are incidental to a facility that would be essential even without such a right. This issue is most likely to arise in the context of a regulated or natural monopoly. For example, the $7^{\text {th }}$ Circuit in $M C I$ v. $A T \& T$ held that the local lines in the old Bell phone system were an essential facility that Bell had to provide to those who competed with it in the market for long-distance telephone services. ${ }^{84}$ Assuming that this conclusion is right as a matter of antitrust law, should the outcome have been different if Bell could point to patents on its telephone switches?

Courts dealing with such situations have generally not paid much if any attention to the incidental effect of the essential facilities claim on intellectual property rights. One example is Associated Press v. United States. ${ }^{85}$ The Associated Press is a joint venture between different newspapers to pool news reporting services and stories. The government brought suit, alleging that AP's policy permitting an existing member to 'blacklist' a proposed new member (usually a local competitor) violated the antitrust laws. The court held that the policy was an unreasonable agreement among horizontal competitors. While the case is not strictly speaking an essential facilities case, it has certain overtones of compelled access on reasonable terms. ${ }^{86}$ The Court made no mention of the fact that AP's members' stories were copyrighted, and that the effect of the decision was to force AP to share those copyrighted works with others admitted to the joint venture. The court's focus was on access to the network itself and the discriminatory effect of AP's policy. While copyright was lurking in the background, the copyrighted stories themselves were not the essential facility to which the complainants wanted access. ${ }^{87}$

On this basis, it seems fair to characterize the law as distinguishing between cases in which the intellectual property right itself is the facility to which the plaintiff wants access and cases in which intellectual property rights exist but are incidental to the control of the facility itself. Only in the former case is the per se rule appropriate. Thus, in $M C I$, MCI presumably wanted access to the local telephone distribution lines that ran into each consumer's home. They were not interested in AT\&T's switches in 
particular, and certainly not in the fact that certain parts of those switches may have been patented. Courts do not seem inclined to allow proof of such an incidental patent right to preclude an essential facilities claim altogether. ${ }^{88}$

One final point is appropriate. Even where the essential facilities doctrine does not compel access to a facility protected by an intellectual property right, Congress may require such access by means of other regulation. The most important example is the Telecommunications Act of 1996. The Telecommunications Act displaces earlier essential facility cases against incumbent telephone companies to the extent that that statute imposes interconnection as a statutory requirement independent of the antitrust requirement. As one court put it,

the 1996 Act imposes duties on the ILECs that are not found in the antitrust laws. Those duties do not conflict with the antitrust laws either; they are simply more specific and far-reaching obligations that Congress believed would accelerate the development of competitive markets, consistently with universal service (which, we note, competitive markets would not necessarily assure). ${ }^{89}$

Thus, the interconnection requirements of the Telecommunications Act are independent of the essential facilities doctrine. They do not give rise to an antitrust cause of action, ${ }^{90}$ but neither are they subject to the limited protection for intellectual property rights we describe in the previous section. ${ }^{91}$ In Verizon Communications v. Law Offices of Curtis V. Trinko, ${ }^{92}$ the Supreme Court held that the regulatory scheme of the Telecommunications Act did not directly preempt antitrust authority. At the same time, the Court reversed the application of the essential facilities doctrine in that case, noting that an essential facilities claim could not be made out where a regulatory statute already compelled access to the facility.

\section{Refusal to License as Facilitation of Monopolization ${ }^{93}$}

An alternative claim sometimes made with respect to unilateral refusals to deal is that the refusal to deal is anticompetitive conduct sufficient to support a monopoly acquisition or maintenance claim under Section 2. In one sense such a claim is narrower than an essential facilities theory. The plaintiff must prove that a specific act - usually refusing to deal with the plaintiff constitutes anticompetitive conduct by a monopolist that contributes to monopolization. The remedy may be limited to the specific conduct, and therefore may be less sweeping than a general obligation to license all comers. Still, the line between the essential facilities doctrine - a law compelling dealing on reasonable and nondiscriminatory terms - and a unilateral refusal to license claim - challenging a refusal to deal on reasonable terms - is a fine one. It is somewhat surprising that courts have 
treated unilateral refusals to license differently, and somewhat more harshly, than they have treated essential facilities claims.

Even so, antitrust decisions are skeptical of claims that involve unilateral refusals to deal. As we have seen, ${ }^{94}$ a party generally has the unilateral right to refuse to deal with whomever it chooses, for commercial reasons, for social or personal reasons, or for no reason at all. ${ }^{95}$ Only where a refusal to deal extends, preserves, creates, or threatens to create significant market power is it subject to scrutiny under Section 2 at all. And even there, a violation of Section 2 requires a court to find that the refusal to deal is itself 'anticompetitive conduct' rather than a permissible exercise of corporate discretion. Courts have rarely done this, primarily in situations where the refusal cuts off a preexisting, profitable business relationship ${ }^{96}$ or where the refusal is conditional rather than unilateral. ${ }^{97}$

Where the refusal to deal involves intellectual property rights, courts are even less willing to condemn it. As we have seen, ${ }^{98}$ the intellectual property rights necessarily embody the power to exclude others from the use of the right. For antitrust law to interfere with that right, there must be clear evidence that the exercise of the right facilitates monopolization that extends beyond the scope of the intellectual property right itself. ${ }^{99}$ Whether and how an antitrust plaintiff can make such a showing has been the subject of much recent controversy in the courts. Different circuits have taken three different approaches, which we detail in the sections below.

\section{Per se legality (Federal Circuit approach)}

The Federal Circuit dealt with the legality of unilateral refusals to license patent rights in two cases at the tail end of the Twentieth Century. The two decisions are somewhat at odds in their holdings. The first case is Intergraph v. Intel, ${ }^{100}$ discussed above for its holding regarding essential facilities. ${ }^{101}$ Intergraph also alleged that Intel's failure to continue to supply it with access to proprietary information, chips, and technical support constituted a refusal to deal that violated Section 2. The court seemed to take the approach discussed above for non-intellectual property cases. It began by observing that

it is well established that in the absence of any purpose to create or maintain a monopoly, the Sherman act does not restrict the long-recognized right of a trader or manufacturer engaged in an entirely private business, freely to exercise his own independent discretion as to parties with whom he will deal. ${ }^{102}$

The court acknowledged that refusals to deal 'may raise antitrust concerns when the refusal is directed against competition and the purpose is to create, maintain, or enlarge a monopoly. ${ }^{, 103}$ Nonetheless, it found no Section 2 
violation based on Intel's refusal to deal, both because it concluded that Intel and Intergraph did not compete at all, and because it saw the fact that Intergraph had sued Intel as a valid reason for Intel to cease giving Intergraph preferential treatment. ${ }^{104}$

Only three months later, the Federal Circuit took a very different approach to unilateral refusals to license intellectual property in In re Independent Service Organizations Antitrust Litigation. ${ }^{105}$ In that case, a group of independent service organizations (ISOs) that provided service for Xerox copiers sued Xerox for violating the antitrust laws because Xerox refused to sell parts to them or their customers. Xerox designed its policy so that it sold parts only to end-users that serviced the machines themselves, or to end-users who hired Xerox to perform service. The effect of the Xerox policy was to drive the ISOs out of the business of servicing Xerox copiers, and to reserve that business exclusively to Xerox.

Xerox counterclaimed for patent and copyright infringement, arguing that it had patents on a number of its parts and copyrights on its service drawings that the ISOs had infringed. Xerox also argued that it could not be held liable for violating the antitrust laws if all it did was unilaterally refuse to sell patented or copyrighted products to the ISOs, regardless of the purpose or effect of that refusal.

The Federal Circuit agreed with Xerox. The court asserted that there was 'no reported case in which a court has imposed antitrust liability for a unilateral refusal to sell or license a patent. ${ }^{106}$ The court held that a patentee's right to refuse to license its intellectual property right was limited only in certain circumstances: where the patent was obtained through fraud, where a lawsuit to enforce the patent was a sham, or where the patent holder uses his 'statutory right to refuse to sell patented parts to gain a monopoly in a market beyond the scope of the patent.,107

In the case before it, the court held that Xerox had not sought to extend its patents beyond the scope of the statutory grant. It noted that patents themselves could cover more than one market, and it held without explanation that Xerox's parts patents entitled it to control the market for service of Xerox copiers as well. ${ }^{108}$ And it refused to inquire into Xerox's motivation for refusing to license its parts patents. ${ }^{109}$ Thus, the Federal Circuit created a per se rule of legality, in accord with earlier statements from both the Second and Sixth Circuits. ${ }^{110}$

The Xerox court also considered Xerox's refusal to license its copyrights. In doing so, it applied Tenth Circuit law. In the absence of any precedent from the Tenth Circuit, the court adopted the First Circuit's approach in Data General, and rejected the Ninth Circuit's approach in Image Technical. ${ }^{111} \mathrm{We}$ discuss both approaches immediately below. 


\section{Rebuttable presumption (First Circuit approach)}

In Data General v. Grumman Systems Support, ${ }^{112}$ the First Circuit confronted an aftermarket exclusion claim similar in some respects to Xerox. In Data General, though, the ISOs were repairing computer hardware, and the 'part' they needed access to was Data General's copyrighted diagnostic software. As in Xerox, Data General cut off access to the software in an effort to increase its own share of the service of its computers. When the ISOs obtained access to the software without permission, Data General sued for copyright infringement, and Grumman counterclaimed for violations of the antitrust laws. The district court rejected Grumman's antitrust claims on summary judgment.

The court engaged in what it described as 'an exhaustive inquiry' into the relationship between copyright and the antitrust laws. ${ }^{113}$ The court sought to read the two statutes in light of each other, rather than giving primacy to one over the other. In particular, it refused to adopt Data General's proposed irrebuttable presumption that a unilateral refusal to license a copyright was legal. Instead, the court held that it must inquire into whether a refusal to license could support a claim for monopolization. ${ }^{114}$ Nonetheless, it created a presumption designed to take the copyrights into account: "[W]hile exclusionary conduct can include a monopolist's unilateral refusal to license a copyright, an author's desire to exclude others from use of its copyrighted work is a presumptively valid business justification for any immediate harm to consumers'. ${ }^{115}$

Applying this presumption, the court held that summary judgment for Data General was appropriate. While there might be a genuine issue of fact as to harm to consumers, the court concluded, there was no evidence to rebut the presumption in this case. Data General's old policy of permitting ISO competition had never led to a competitive market, so the withdrawal of its support couldn't be proof of anticompetitive effect. The copyrights were valid, the copyrighted diagnostic software was innovative, and the court was unwilling to inquire into Data General's motivation in enforcing the copyrights. ${ }^{116}$

Thus, the First Circuit refused to apply a per se rule, settling instead for a strong presumption that even a monopolist acts lawfully by refusing to license its copyright. Xerox endorsed this rebuttable presumption in copyright (as opposed to patent) cases, saying it is 'consistent with both the antitrust and the copyright laws'. ${ }^{117}$

\section{The role of intent (Ninth Circuit approach)}

The Ninth Circuit has taken a third approach in a case with facts strikingly similar to Xerox, and indeed one that arose in the same industry. Image Technical Services v. Eastman Kodak ${ }^{118}$ also involved an antitrust claim by 
ISOs in the photocopier industry who had been cut off after years of coexistence, in this case by Kodak. Unlike Xerox, however, Kodak did not counterclaim for patent or copyright infringement. The case was litigated for almost ten years, including one trip to the US Supreme Court, ${ }^{119}$ before Kodak on remand asserted as a defense that some of its parts were covered by patents and its service software was covered by copyrights.

The Ninth Circuit upheld a jury finding of antitrust liability. ${ }^{120}$ It found that Kodak had power in the market for service of Kodak copiers, and that Kodak had engaged in anticompetitive conduct by refusing to sell parts to ISOs, or to end users who dealt with ISOs. The court then proceeded to consider whether Kodak could offer a legitimate business justification for its conduct. The court recognized that while intellectual property owners are not immune from antitrust liability, 'patent and copyright holders may refuse to sell or license protected work' ${ }^{121}$ and that no prior case imposed antitrust liability on the basis of a unilateral refusal to license. ${ }^{122}$ The court pointed out, however, that other sorts of conduct, such as concerted acts under Section 1 or extension of a patent beyond the lawful scope of its grant, could violate the antitrust laws. ${ }^{123}$

With respect to unilateral refusals to license intellectual property, the Ninth Circuit endorsed the rebuttable presumption adopted in the Data General case. ${ }^{124}$ Nonetheless, the court refused to give Kodak the benefit of the presumption because it found the presumption had been rebutted. ${ }^{125}$ Specifically, the court pointed to two pieces of evidence. The first was the fact that Kodak had thousands of parts, but that only 65 of those parts were patented. The second factor was one that the Data General court specifically rejected: the fact that Kodak's intellectual property justifications were pretextual and adopted only long after the fact. ${ }^{126}$ The court defended the role of intent in the analysis, saying that 'neither the aims of intellectual property law, or the antitrust laws justify allowing a monopolist to rely upon a pretextual business justification to mask anticompetitive conduct. ${ }^{127}$

The court sought to cabin the likely effect of its holding. It noted that 'some weight [must] be given to the intellectual property rights of the monopolist', and expressed 'serious concern' about the effect of claims like the one it permitted on the value of intellectual property rights. ${ }^{128}$ Nonetheless, Image Technical adopts a modified form of the Data General presumption, both one that applies to patents as well as copyrights and one that allows evidence of the defendant's intent in adopting its policy to overcome the presumption that a refusal to license is legitimate.

\section{Reconciling these approaches}

On their face, the opinions in Xerox, Data General and Image Technical present a rather stark conflict. Despite strikingly similar facts, the courts not 
only reach different results but take fundamentally different approaches to reconciling antitrust and intellectual property law. ${ }^{129}$ In this section, we suggest some ways that these approaches might be reconciled. In the absence of such a reconciliation, however, the issue is ripe for review by the Supreme Court. ${ }^{130}$

a. Distinguishing legitimate refusals to license from post hoc justifications. One way to reconcile the Image Technical, Xerox and Data General decisions may be to focus on the facts of each of the cases. While in one sense the three decisions involved very similar facts - indeed, Image Technical and Xerox arose in the same industry - the way in which the unilateral refusal issue came to the court was very different. In Xerox, the antitrust claim by the ISOs was met immediately by a counterclaim for patent and copyright infringement. ${ }^{131}$ By contrast, in Image Technical patents were not even an issue until many years into the litigation. Even then, Kodak never alleged infringement of its intellectual property rights, but merely asserted that the fact that it owned patents covering some of its parts immunized it from antitrust liability.

This difference in facts offers the most plausible way to understand the Ninth Circuit's much-criticized discussion of 'intent'. As noted above, the Ninth Circuit did in fact adopt the Data General presumption that a refusal to license intellectual property rights was a legitimate business decision. ${ }^{132}$ It departed from the First Circuit approach only in permitting evidence of the antitrust defendant's intent to rebut the presumption. A narrow reading of the Ninth Circuit's opinion - and indeed we think the reading the court most likely intended - would not open the door to evidence of intent to injure competition. Rather, it would merely permit the antitrust plaintiff to demonstrate that there was no legitimate refusal to license intellectual property rights at stake, and that the invocation of intellectual property rights was a 'pretext' - a post hoc justification for conduct that had nothing to do with intellectual property. Read in this light, Image Technical would not open the door to evidence of a defendant's intent except in very specialized circumstances. While the evidentiary disputes engendered by Image Technical's focus on statements of intent will likely be substantial, this reading helps to cabin them somewhat.

We should note, however, that this understanding of Image Technical doesn't necessarily justify the court's result. At most, proof of such a pretext could strip Kodak of any special immunity its intellectual property rights might have conferred on it. But even owners of unpatented parts have a general right unilaterally to refuse to deal with particular customers. ${ }^{133}$ Thus, the court's pretext finding merely permits it to reject one possible business 
justification relating to intellectual property; it says nothing about how other, non-intellectual-property-related justifications might fare.

It is also worth noting that none of the three cases were truly unilateral refusals to license in the pure sense. In each case, what was really at issue was a tying arrangement in which customers could get parts only if they also bought service. Because all of the cases were ultimately litigated on grounds of monopolization rather than tying, ${ }^{134}$ the courts approached them as unilateral refusals to license. But the rather unusual factual hybrid may account for differences in the cases. Xerox expressly recognized that tying arrangements involving patents could be illegal $;{ }^{135}$ it simply didn't apply that rule to the conditional agreement at issue in the case before it. By contrast, while Image Technical did not apply the rules of tying, it was clearly concerned that Kodak was using its intellectual property rights as a cover for what was in effect a tying arrangement. It may be, therefore, that the courts simply focused on different aspects of the cases before them, and that were the Federal Circuit to consider a pure tie - or the Ninth Circuit to consider a pure refusal to license - they would reach results in accord with their sister circuits.

b. Presumptions and risks of error. Even once these factual differences are taken into account, the three circuits take different approaches to the problem of unilateral refusals to license. While all three circuits are willing to presume that an intellectual property owner has the power to refuse to license or use its rights, only the Federal Circuit has made that presumption irrebuttable, and then only for patents. ${ }^{136}$ Both the First and Ninth Circuits are willing to permit some sorts of evidence to rebut the presumption of legitimacy. They disagree, however, about what kinds of evidence are acceptable.

This disagreement over the right presumption is fundamentally about the costs of various sorts of error. An irrebuttable presumption of legality, like per se rules of illegality, establishes relatively clear rules for behavior. It may be applied to reach problematic results in some cases, however. By contrast, rebuttable presumptions offer somewhat less predictability, but permit courts to delve into the factual context of the cases before them in order to determine competitive effect. In deciding which rule is appropriate, therefore, courts must consider three factors: the risk of erroneously condemning procompetitive conduct, the risk of erroneously permitting anticompetitive conduct, and the administrative and uncertainty costs associated with a more flexible standard. ${ }^{137}$

An irrebuttable presumption may be appropriate given these factors, but only within narrow confines. Where the core right of exclusion is at stake, prohibiting enforcement of an intellectual property right will likely impose significant uncertainty costs on all intellectual property owners. Further, 
while there may be anticompetitive effects from a unilateral refusal to license a valid intellectual property right, those effects are a natural consequence of the intellectual property laws themselves, not the defendant's conduct. By contrast, where the refusal to license is not truly unilateral, where it is conditioned in an effort to expand the scope of the intellectual property right, or where it covers rights not granted by the intellectual property laws, the irrebuttable presumption should not apply. Indeed, it is not clear that any presumption of legality is appropriate in these sorts of cases.

Thus, while we agree in principle with the legal rule established in Xerox, we believe it will be applicable only in a very narrow set of cases. Indeed, as noted above, it is not clear that Xerox itself was truly a case involving an unconditioned, unilateral refusal to license. In the sections that follow, we discuss some issues relating to the proper scope of any such presumption. ${ }^{138}$

\section{E. Duty to Continue Dealing}

Courts are sometimes willing to impose antitrust duties on monopolists to continue existing relationships in circumstances in which they would not be required to enter into new relationships. A notable example is Aspen Skiing Co. v. Aspen Highlands Skiing Corp. ${ }^{139}$ In that case, Highlands and Ski Co. operated competing ski mountains in Aspen, Colorado. There are four mountains in Aspen; while they were originally individually owned, at the time of litigation Ski Co. had purchased three of the four. The four mountains had a long-standing joint lift ticket arrangement, under which a skier could buy one multi-day ticket good for any mountain. When Ski Co. terminated the arrangement, Highlands sued, arguing that Ski Co. was trying to drive it out of business. The jury found that Ski Co. had acted anticompetitively by ending the arrangement, and that the effect was to enable it to monopolize the market. The Supreme Court affirmed. It refused to decide whether the joint lift ticket was an essential facility, instead concluding that Ski Co.'s failure to continue a profitable existing business relationship without a legitimate justification itself violated Section 2. ${ }^{140}$ The Court did not hold that a monopolist had a duty to deal with its rivals, though it noted that a refusal to deal 'may have evidentiary significance'. ${ }^{141}$ The Court focused significant attention, though, on Ski Co.'s refusal to continue a profitable existing business relationship with Highlands. It noted that the joint lift ticket provided benefits to both sides, and that there were no plausible changes in factual circumstances to render the joint lift ticket unprofitable to Ski Co. It found sufficient evidence "that Ski Company was not motivated by efficiency concerns and that it was willing to sacrifice short-run benefits and consumer goodwill in exchange for a perceived long-run impact on its smaller rival'. ${ }^{142}$ This in turn was sufficient to violate Section 2. 
Aspen may well be sui generis. ${ }^{143}$ Indeed, the Supreme Court has described it as existing 'at or near the outer boundary of $\S 2$ liability. ${ }^{144}$ But to the extent it establishes a general principle of law, that principle seems to be that terminating an existing business relationship without a legitimate efficiencyrelated reason may violate the antitrust laws even where a monopolist would be under no obligation to enter into a new relationship along the same lines. ${ }^{145}$ The Supreme Court's decision in Kodak v. Image Technical Services ${ }^{146}$ seemed to give further support to the idea that terminating existing relationships can be problematic.

Neither case involved intellectual property, at least as presented to the Supreme Court. ${ }^{147}$ The question for our purposes is whether Aspen and Kodak might be read to compel an intellectual property owner to continue an existing license arrangement, even though the same owner would not be obligated to enter into a new license arrangement. Notwithstanding Aspen, we think the answer must be no.

In the first place, Xerox, Data General, and Image Technical all involved refusals to continue an existing business relationship. Despite this fact, the courts in Xerox and Data General found no antitrust violation. While the court did find a violation in Image Technical, it did not focus on the continuing nature of the relationship, but rather on the fact that intellectual property rights were raised only as a pretext. Xerox did not consider the continuing nature of the relationship relevant at all. Only Data General suggested it might be relevant in the intellectual property context. The court there refused to apply Aspen only 'because we are unable to view DG's market practices in both competitive and noncompetitive condition', and so unable to infer that Data General's change of heart occurred because it was now a monopolist. ${ }^{148}$ The courts to consider the issue have not generally treated the existence of a prior relationship as particularly important.

We think that there are reasons to be particularly wary of reading Aspen to compel continued dealing in the intellectual property context. Intellectual property licenses are generally quite complex, and they often involve technologies and markets that change rapidly. Locking companies into existing business relationships seems particularly inappropriate in fastchanging markets. Intellectual property licenses are often exclusive, in whole or in part; locking in relationships in such a context may prevent competition by other potential licensees down the road. Further, as a general matter antitrust law wants to encourage the licensing of intellectual property, since the alternative may be monopoly or at least more centralized control over production. ${ }^{149}$ Forcing companies to continue an existing license relationship may have the perverse effect of discouraging them from licensing their intellectual property rights in the first place. In short, we think it would be a 
mistake to depart from the presumptions that protect unilateral refusals to license merely because the parties had had a relationship in the past.

\section{F. Determining the Scope of Intellectual Property Rights ${ }^{150}$}

It should be clear that any presumption of legality based on a unilateral refusal to license intellectual property rights extends only so far as those rights themselves do. As an initial matter, therefore, efforts to enforce or refusals to license clearly invalid intellectual property rights, or efforts to enforce valid intellectual property rights against conduct that clearly does not infringe, must be outside the protection of the presumption. ${ }^{151}$ Xerox and Data General both explicitly acknowledge that antitrust claims can be based on sham litigation or Walker Process allegations without interfering with the proper scope of the intellectual property laws.

The point is more general, however. The protection of the intellectual property laws should extend only as far as those laws themselves extend. A refusal to license will be presumed legitimate if the conduct for which a license is withheld is in fact within the scope of an intellectual property right. But the presumption should not extend to protect refusals to license that go beyond the scope of the intellectual property rights themselves. ${ }^{152}$ That doesn't mean that the refusal to provide, say, uncopyrighted information is illegal, of course. As with any other unilateral refusal to deal outside the intellectual property context, it will normally be legal. Rather, the point is merely that the Xerox-Data General presumption cannot protect conduct that is itself outside the scope of an intellectual property right.

United States v. Microsoft is an example. ${ }^{153}$ Among the government's allegations of anticompetitive conduct in that case were challenges to Microsoft's refusal to permit computer hardware manufacturers to introduce their own boot-up screen or to modify the appearance of the Windows desktop in any way, notably by removing the Internet explorer icon. In the pretrial proceedings, ${ }^{154}$ Microsoft moved for summary judgment, arguing that because Windows was copyrighted, it could not violate the antitrust laws by refusing to let people alter the program. Microsoft claimed that its license restrictions on hardware manufacturers 'merely highlight and expressly state the rights that Microsoft already enjoys under federal copyright law'. The district court rejected this argument on summary judgment. It held:

Microsoft argues that it 'may refrain from vending or licensing and content [itself] with simply exercising the right to exclude others from using [its intellectual] property.' See Fox Film Corp. v. Doyal, 286 U.S. 123, 127, 52 S.Ct. 546, 76 L.Ed. 1010 (1932). But whatever copyright protection Microsoft enjoys in its software is not unlimited. For example, copyright in a computer program does not extend to its functional aspects. See, e.g., Lotus Dev. Corp. v. Borland Int'l, Inc., 49 F.3d 807 
(1st Cir.1995), aff'd by an equally divided Court, 516 U.S. 233, 116 S.Ct. 804, 133 L.Ed.2d 610 (1996). It does not preclude design choices dictated by necessity, cost, convenience or consumer demand. See, e.g., Apple Computer, Inc. v. Microsoft Corp., 35 F.3d 1435, 1442 (9th Cir.1994) (user interface of computer program entitled to only limited protection against 'virtually identical' copying, because of license and because of limited number of different ways the underlying idea can be expressed); Computer Assocs. Int'l v. Altai, 982 F.2d 693, 715 (2d Cir.1992) (significant portions of structure, sequence, and organization of program may be copied in order to write similar program to run on different platform). And it does not render inviolate portions of the program that are not original to its creator.

Furthermore, copyright law does not give Microsoft blanket authority to license (or refuse to license) its intellectual property as it sees fit. A copyright does not give its holder immunity from laws of general applicability, including the antitrust laws. Copyright holders are restricted in their ability to extend their control to other markets. They may not prevent the development and use of interoperable programs by competitors. Antitrust liability may also attach to other anticompetitive licensing restrictions involving copyrighted works. ${ }^{155}$

The court didn't deny that Microsoft owned a valid copyright in its Windows operating system. But it noted that ownership of an intellectual property right does not give the owner carte blanche over all uses of the intellectual property. In particular, the court found that Microsoft failed to demonstrate that the hardware manufacturers would be violating its copyrights if they made the prohibited alterations to the start-up and home screens. The court rejected Microsoft's argument that it had a moral right of integrity in its software, and held that 'the extent of copyright protection in the specific portions of the software plaintiffs seek to modify' presented a disputed issue of fact.

After trial, the court found that 'Microsoft has presented no evidence that the contractual (or the technological) restrictions it placed on OEMs' ability to alter Windows derive from any of the enumerated rights explicitly granted to a copyright holder under the Copyright Act'. ${ }^{156}$ As a result, it could not benefit from the presumption of legitimacy, however articulated, that attends refusals to license intellectual property rights. Microsoft hadn't simply exercised its copyright rights; it had sought to impose on hardware manufacturers a restriction that copyright law did not support. ${ }^{157}$

Assuming the court was right as a matter of copyright law to conclude that the minor modifications in question didn't constitute derivative works, its antitrust conclusion seems correct as well. A presumption of legitimacy in refusing to license an intellectual property right - and certainly an irrebuttable presumption of the sort Xerox adopts for patents cases - is appropriate only where there is in fact a refusal to license an intellectual property right. Where the intellectual property owner seeks to expand by contract the scope of rights allocated to it, a very different issue is presented. ${ }^{158}$ Whether or not patent and copyright law permit such contractual expansions, the contracts are 
surely not immune from antitrust liability. Indeed, such licensing restrictions are the primary source of antitrust violations involving intellectual property.

A prerequisite to applying the Xerox or Data General presumption, therefore, is proof not only that the defendant owns a valid intellectual property right, but that the use the plaintiff proposes would in fact infringe that right. This is more likely to be an issue in copyright than patent law, because copyright contains many more restrictions on the scope of the right. Copyright protection doesn't extend to ideas, facts, functional elements, scenes a faire, or unoriginal portions of a work. ${ }^{159}$ It covers only duplication, adaptation, distribution, and public performance and display, not all uses that might be made of a work. ${ }^{160}$ And it is subject to numerous exceptions and defenses, including not only the fair use doctrine ${ }^{161}$ but also a complex series of compulsory licensing schemes. ${ }^{162}$ The latter are particularly important; it would obviously be anomalous to conclude that copyright law protected a refusal to license in circumstances in which copyright law itself required licensing on defined terms.

While the rights granted a patentee are much stronger - including the right to control any making, using, selling, offering for sale, or importing of the patented invention ${ }^{163}$ - they too are not unlimited. Patent law restricts a patentee's control through the exhaustion doctrine, ${ }^{164}$ through the reverse doctrine of equivalents, ${ }^{165}$ and most importantly through limitations tied to the scope of the patent claims. It is not enough to assert ownership of a patent right that covers a product in a general sense; for a refusal to license to be protected by the Xerox presumption, the patent must be infringed by the proposed use. $^{166}$

\section{G. Distinguishing Antitrust Violations from the Scope of Antitrust Remedies}

A second limitation on the scope of the Xerox and Data General presumptions concerns the distinction between antitrust violations and antitrust remedies. In this chapter we have discussed whether a unilateral refusal to license an intellectual property right can violate the antitrust laws, either on its own (under some sort of essential facilities doctrine) or as anticompetitive conduct sufficient to support a Section 2 claim when coupled with proof of monopoly power and causation. Except in the most unusual circumstances, a pure unilateral refusal to license cannot support such a claim.

A different set of issues is presented by judicial efforts to compel licensing of an intellectual property right as a remedy for other sorts of antitrust violations. Compulsory licensing has a long history as an antitrust remedy, ${ }^{167}$ and may be quite appropriate depending on the nature of the antitrust 
violation itself. So long as the refusal to license is not a part of the finding of violation, compelled licensing as an antitrust remedy doesn't run afoul of the presumption we have discussed in this section. ${ }^{168}$ Compelling licensing of intellectual property rights as an antitrust remedy does present a variety of other issues, of course, which are beyond the scope of this chapter. ${ }^{169}$

\section{DISTINGUISHING UNILATERAL FROM CONDITIONAL OR CONCERTED REFUSALS}

This chapter treats unilateral refusals to license intellectual property rights, not concerted and conditional refusals to deal. Nonetheless, because of the very different rules applied to unilateral refusals to license, defining what is and what isn't - a 'unilateral' refusal becomes quite important. In this section we distinguish true unilateral refusals to license both from concerted action and from 'conditional' refusals.

\section{A. Concerted Refusals to Deal}

Antitrust law draws a fundamental distinction between unilateral and concerted action. Unilateral conduct is generally dealt with under Section 2 of the Sherman Act. By contrast, Section 1 of the Sherman Act separately prohibits unreasonable agreements in restraint of trade. The Section 1 prohibitions on conduct are, generally speaking, stricter than the Section 2 rules. The law will condemn certain combinations among competitors per se, and even where the per se rule does not apply Section 1 does not always require a showing of market power for illegality. ${ }^{170}$

This fundamental distinction plays an historic role in intellectual property cases as well. Courts have distinguished between an intellectual property owner's exercise of its lawfully granted right and that same owner's agreement with others to constrain their pricing or output decisions. Agreements concerning the disposition of intellectual property rights can be illegal even when unilateral action is not. ${ }^{171}$ There are myriad examples; among the most common types of concerted conduct relating to intellectual property are tying arrangements, patent pools and cross-licenses, grantback clauses and field of use restrictions. ${ }^{172}$

Because of this fundamental distinction, it should be clear that the cases we have discussed apply only to unilateral and not concerted action by intellectual property owners. In Xerox, for example, the court expressly discussed the requirements for monopolization under Section 2 of the Sherman Act. ${ }^{173}$ The Xerox court considered only allegations that a patentee's 
unilateral efforts to 'enforce the statutory right to exclude others' violated the antitrust laws. ${ }^{174}$ There is nothing in the opinion (or in Data General or Image Technical) ${ }^{175}$ to suggest that the court meant its ruling to extend to situations in which the patentee agreed with another to restrict competition. The body of law on unilateral refusals to license cannot displace the voluminous precedent concerning either horizontal or vertical agreements.

\section{B. Conditional Refusals to Deal}

Determining that Xerox and related cases do not apply to concerted action doesn't resolve the issue of their scope, however. The line between individual and concerted acts in antitrust law has historically proven quite malleable. We must therefore inquire whether the line of cases dealing with 'unilateral' refusals to license covers only 'pure' unilateral refusals, or whether it ought to be extended to circumstances in which an intellectual property owner effectively enters into an agreement imposing conditions on a licensee, but structures the transaction in such a way that the conditions are unilaterally announced rather than being part of an express agreement.

\section{Relevance of Xerox}

Xerox did not hold that unilateral conduct by an intellectual property owner enforcing a patent right can never be illegal under Section 2. Rather, it identified three circumstances in which a patent owner could violate Section 2, and discussed each in some detail. First, a patentee could enforce a patent obtained by fraud - a so-called Walker Process violation. Second, a patentee could engage in sham litigation. Both of these exceptions are wellrecognized, and involve a patentee asserting in court a right it does not legitimately own. ${ }^{176}$ Finally, the court noted the 'undisputed premise that the patent holder cannot use his statutory right to refuse to sell patented parts to gain a monopoly in a market beyond the scope of the patent. ${ }^{177}$ This suggests that even unilateral conduct may be illegal under Xerox if the effect of that conduct is to extend the power of an intellectual property right beyond its lawful scope.

In the course of summarizing the rule it was adopting, however, the Xerox court chose language much more limiting than in its detailed discussion:

In the absence of any indication of illegal tying, fraud in the Patent and Trademark Office, or sham litigation, the patent holder may enforce the statutory right to exclude others from making, using or selling the claimed invention free from liability under the antitrust laws. ${ }^{178}$ 
It is possible to read this language as foreclosing any antitrust claim not based on tying, Walker Process fraud, or sham litigation, and indeed one court has done so. In Townshend v. Rockwell Int'l, the court reasoned that since 'a patent owner has the legal right to refuse to license his or her patent on any terms, the existence of a predicate condition to a license agreement cannot state an antitrust violation' ${ }^{179}$ We do not think the court intended such a sweeping holding, however. ${ }^{180}$ In the first place, as noted above, the court's more detailed discussion included anticompetitive extension of a patent right, not just tying, within its ambit. It is likely, therefore, that the court's later mention of such cases as 'tying' claims was intended to restate rather than to undo its prior discussion. Second, the Supreme Court has made it clear that 'power gained through some natural and legal advantage such as a patent [or] copyright, ... can give rise to liability if "a seller exploits his dominant position in one market to expand his empire into the next". ${ }^{181}$ For the Federal Circuit, to restrict antitrust claims involving valid patents to tying cases would appear to conflict with the Supreme Court's most recent pronouncement on the issue. ${ }^{182}$ An alternative reading of Xerox would require the courts to jettison a century of jurisprudence involving the legality of conditions imposed by intellectual property owners on licensees. Even if a Federal Circuit panel had the power to make such a sweeping change in the law, we should not lightly impute to the court a desire to do so. Finally, at least for exclusive dealing cases, Section 3 of the Clayton Act forecloses such a reading, since it clearly applies to unilateral conduct involving goods 'whether patented or unpatented' ${ }^{183}$ Exclusive dealing, at least, must therefore fall outside the Xerox rule.

A more plausible reading of Xerox is that the court intended to encompass within its new rule of per se legality only conduct within the legitimate scope of the intellectual property right. Conduct that seeks to expand the scope of an intellectual property right will not be protected from antitrust liability. What conduct that includes remains to be fully determined, however. We consider this issue in the following section.

\section{Distinguishing Section 1 and Section 2 cases}

In light of the preferential treatment of unilateral refusals to license, intellectual property owners may be expected to attempt to characterize their conduct as a unilateral refusal to license. For example, suppose that a patent owner wishes to tie a license to its patent to the purchase of a staple article of commerce - say, salt. If the patent owner enters into contracts with licensees requiring them to buy salt from it, the contract is unquestionably a tying arrangement, and under traditional antitrust law may well be illegal. ${ }^{184}$ Suppose instead that the patentee were merely to announce to the world that it was free to deal with whomever it chose, and that henceforth it would only 
grant licenses to those who 'voluntarily' chose to buy salt from the patentee. Does the change in the form of the restriction - from a contract to a unilateral announcement - change the legal result? ${ }^{185}$

Antitrust law has faced a similar characterization problem in trying to distinguish vertical agreements treated under Section 1 from permissible unilateral conduct. ${ }^{186}$ The maker of a product is generally free to decide to whom it will sell, and to terminate its buyers at will. ${ }^{187}$ But this right does not include the right to impose certain types of conditions on those buyers notably but not exclusively tying arrangements and resale price restrictions. The result has been a rather complex line-drawing process, in which courts permit termination of buyers who don't adhere to certain conditions but forbid any sort of negotiation or other effort to convince buyers to comply with the conditions. ${ }^{188}$ This body of law can justifiably be criticized as extremely formalist.

This set of rules has been expressly applied to intellectual property licenses by the Fourth Circuit in Service \& Training Inc. v. Data General. ${ }^{189}$ That case, like the First Circuit's decision in Data General, involved Data General's decision to stop supplying diagnostic software to independent service organizations repairing Data General computers for customers. The plaintiff there alleged that Data General's refusal to sell them copies of the diagnostic software, while making the software available to its ultimate customers who wished to self-service, constituted a de facto tying arrangement. The court rejected this theory because it found only a unilateral decision by Data General as to who it wished to do business with:

Appellants' evidence at bottom shows nothing more than a unilateral decision by Data General to license MV/ADEX to [end-users] but not to others. The fact that Data General has selectively licensed MV/ADEX is not evidence of an illegal tying agreement. Data General may lawfully license MV/ADEX to whomever it chooses. ${ }^{190}$

The court made it clear, however, that the plaintiff's tying theory could have proceeded had they demonstrated an agreement of some sort between Data General and its customers. Data General avoided the reach of tying law because its decision was unilateral - it simply chose to sell its software to customers but not to competitors.

In applying these rules to intellectual property cases, it is important to keep in mind several limits on the ability of intellectual property owners to stretch the Xerox rule to cover conditional conduct. First, notwithstanding the antitrust advantages of unilateral action, there are a number of powerful incentives for intellectual property owners to enter into express licensing agreements. Many intellectual property licenses involve a continuing relationship between the parties in which not only patent rights but also trade 
secrets and other forms of know-how are exchanged. In such a circumstance, it is in the interest of both parties to clearly set out the rights and obligations of each. While it is perhaps possible to imagine writing a 'unilateral action policy' that takes these complexities into account - in which an intellectual property owner 'announces' that they will license only to parties that agree to a list of conditions - that is surely not the sort of unilateral conduct the Xerox court had in mind. Where an intellectual property owner seeks to compel certain types of conduct or obligations from its licensees rather than merely to distinguish between groups of buyers, the resulting relationship is an agreement on conditions, not a pure unilateral refusal to license.

Second, many of the conditions intellectual property owners might wish to impose involve promises by licensees to act or refrain from acting in certain ways in the future. Grantback clauses, some sorts of ties and reciprocal deals, confidentiality and noncompetition obligations cannot be monitored ex ante. In each case, the intellectual property owner is granting a right today in return for a promise that the licensee will act in a certain way tomorrow. What such an owner needs is an enforceable right to compel a licensee to act as promised in the future. That in turn requires an enforceable agreement setting out the condition, not just the power to decide unilaterally whom to license today. This is particularly true with respect to certain types of intellectual property transactions - trade secrets, know-how, access to unprotectable facts - in which the disclosure of the know-how is irreversible.

Third, the Sherman Act is not the only antitrust statute that might come into play where a license is conditioned. In particular, Section 3 of the Clayton Act prohibits the imposition of certain types of conditions - notably ties and exclusive deals - in transactions in commodities. ${ }^{191}$

Finally, it is worth emphasizing that even under Xerox an intellectual property owner's right to unilaterally refuse to license is not absolute. Xerox followed Data General in applying only a rebuttable presumption of legitimacy in copyright as opposed to patent cases. Microsoft is to the same effect. ${ }^{192}$ One court has held that Xerox's irrebuttable presumption does not apply to trade secrets. ${ }^{193}$ Further, as noted above, even unilateral refusals to license patents will not be immune from Section 2 scrutiny if they operate to expand a patent beyond its lawful scope. Thus, even if a patentee succeeds in characterizing a conditional refusal to deal (such as a tie) as 'unilateral' conduct, the patentee will still face potential liability under the Supreme Court decision in Eastman Kodak for using the condition to expand the effective scope of the right.

This is, we think, as it should be. The preferential rules governing unilateral conduct are designed to protect an intellectual property owner in the lawful exercise of the rights the law has given it. If the intellectual property owner seeks more than the intellectual property laws expressly 
permit, it must contend with the limits that antitrust law places on conditional and concerted conduct. ${ }^{194}$

\section{Acquisitions of Intellectual Property}

The pure case of a unilateral refusal to license must also be distinguished from cases in which the antitrust claim is based on the acquisition of intellectual property rights through merger or purchase. Such acquisitions are treated under Section 7 of the Clayton Act. In SCM Corp. v. Xerox Corp., ${ }^{195}$ the court distinguished between Xerox's refusal to license its patents, which it found to be permissible, and Xerox's original acquisition of those patents, which presented a Section 7 issue. A company could violate Section 7 by accumulating too strong a patent portfolio through acquisition, ${ }^{196}$ but if the acquisition of the patents didn't violate the antitrust laws, the company was free to enforce those patents just as if it had developed them internally. ${ }^{197}$

\section{Intel Decisions and Cross-Licensing}

Adverse effects on competition are not limited to higher prices and reduced output. They can also include adverse effects on innovation incentives. In both government and private suits against Intel in the late 1990s, the plaintiffs charged that Intel had reduced competitors' incentives to innovate by demanding a royalty-free license to the patents of any company it did business with. In particular, the FTC charged that Intel had cut off business dealings with Intergraph, Compaq, and Digital Equipment Corporation, in each case after the company sued or threatened to sue it for patent infringement. ${ }^{198}$ The government alleged that the effect of Intel's blanket policy of demanding royalty-free licenses and refusing to deal with those who sued it for patent infringement was to reduce others' incentives to innovate in the market Intel dominated, since they could not obtain revenue from licensing patents to the most likely licensee. ${ }^{199}$ Similarly, Intergraph brought a wide-ranging antitrust suit against Intel based on the same conduct. Both of these claims were filed under Section 2, and both challenge Intel's refusal to continue dealing with Intergraph. However, they do not seem appropriately within the scope of the Xerox rule, because the refusal to license is not absolute. Rather, the license is conditioned on the licensee's willingness to grant a royalty-free license to its intellectual property to Intel. ${ }^{200}$

The resolution of these two cases differed. In the private action, the Federal Circuit reversed a preliminary injunction against Intel. ${ }^{201}$ The court rejected a wide variety of antitrust theories proffered by the plaintiffs, including tying ${ }^{202}$ and the essential facilities doctrine. ${ }^{203}$ In rejecting Intergraph's monopolization claim, the court emphasized that Intergraph was 
an Intel customer, and sold products in a different, downstream market. Since the companies were not direct competitors in product sales, the court reasoned, Intel could not be held liable for monopolizing Intergraph's market ${ }^{204}$ By contrast, the FTC suit ended with a consent decree in which Intel agreed not to stop dealing with companies merely because they sued it to enforce intellectual property rights. Intel reserved the right to end relationships with companies for a variety of legitimate business reasons, however. ${ }^{205}$

The strength of the economic theory behind these cases is uncertain. As an initial matter, the Federal Circuit was almost certainly too facile in its rejection of Intergraph's claim. It is true that Intel and Intergraph are in a vertical relationship in the products market, and that Intel has not made a serious effort to integrate downstream into Intergraph's market. As a result, Intel cannot possibly be held liable for monopolizing the graphics workstation market, where Intergraph competes. But that does not dispose of the case. Intergraph owned patents that conferred rights in Intel's core market for microprocessors. Intel's actions were designed to obtain a royalty free license to those patents and therefore arguably to protect its dominance in the microprocessor market. The Federal Circuit did not focus on Intergraph's ownership of intellectual property assets that competed directly with Intel. But that fact seems critical to the case, as the FTC properly recognized.

Nonetheless, it does not necessarily follow that Intel has done anything wrong. As we have seen, companies have a strong right to refuse to deal with individual firms for any legitimate business reason or even for no reason at all. ${ }^{206}$ And as the Federal Circuit observed, the fact that a company is suing you would seem to be a legitimate reason to stop doing business with them. ${ }^{207}$ It would seem anomalous to insulate a company from termination by virtue of the fact that it had sued its supplier, when companies with less adversarial business relationships are not so protected. To the extent that Intergraph complained merely of being terminated by Intel because it sued them, therefore, we believe the Federal Circuit was right to reject the complaint.

The FTC alleged something more, however: a pattern of refusing to deal with multiple buyers unless they grant Intel blanket access to their intellectual property rights. The FTC's Section 2 case further depended critically on the facts that Intel had monopoly power in the microprocessor market, and that the effect of its policy was to discourage innovation by actual or potential competitors in that market ${ }^{208}$ by reducing or eliminating the value of their intellectual property related to microprocessors. As a result, the FTC argued, Intel helped maintain its monopoly in the microprocessor market by discouraging leapfrogging innovations. ${ }^{209}$ We think the FTC's claim is critically dependent on proof of these facts. In particular, it is important to distinguish the FTC's allegations of an industry-wide pattern of conduct 
directed at discouraging innovation from the complaints of a single terminated buyer.

Even with these limitations, the FTC's theory is somewhat troubling. Companies in many industries, including semiconductors, regularly enter into royalty-free cross-licensing agreements. The law normally treats these agreements as procompetitive because they free both parties to compete on the merits without being restricted by overlapping or blocking patent rights. $^{210}$ To the extent Intel is attempting to avoid being 'held up' by patentees making unreasonable claims, its demand for a license seems not only legitimate but procompetitive. ${ }^{211}$ At a minimum, these possible procompetitive effects must be taken into account before concluding that any such licensing policy violates Section 2. Claims based on unilateral refusals to license an intellectual property right are rarely successful in the US. Where they are successful, it is normally because the refusal is not truly unilateral, but represents an effort to condition a license on some anticompetitive end.

\section{NOTES}

1 This chapter is adapted from a treatise by the same authors: Hovenkamp, H., Janis, M. D. and M. A. Lemley (2004), IP and Antitrust: An Analysis of Antitrust Principles Applied to Intellectual Property Law, Aspen Law \& Business (from now on, IP and Antitrust).

2 We distinguish the enforcement of a valid intellectual property right from situations in which the intellectual property owner is alleged to have attempted to enforce an invalid or not-infringed intellectual property right. Those cases are discussed in Chapter 11 of our treatise IP and Antitrust (see supra Note 1).

3 For a useful theoretical treatment of the problem, see Baxter, William (1966), 'Legal Restrictions on Exploitation of the Patent Monopoly: An Economic Analysis', Yale L.J.,76, 267.

4 We discuss only internally developed intellectual property rights in this chapter. For a discussion of the rules that apply to intellectual property rights acquired from others, see $I P$ and Antitrust (supra Note 1), §14.4.

210 US 405 (1908).

Id. at 428 (citing district court)

Id. at 429. There are myriad other cases permitting non-use. See e.g. United States v. Studiengesellschaft Kohle, 670 F.2d 1122, 1127 (DC Cir. 1981).

835 USC $\$ 271(\mathrm{~d})(4)$. While the statute refers to patent misuse, and does not directly cover antitrust violations, the policy it expresses is still relevant.

9 See e.g. Metallurgical Indus. v. Fourtek, 790 F.2d 1195, 1200 (5 $5^{\text {th }}$ Cir. 1986) (licensing secret process to two companies wasn't sufficient disclosure to end trade secret protection).

10 See e.g. Harper \& Row v. Nation Ents., 471 US 539 (1985) (right of first publication specifically protected); Salinger v. Random House, Inc., 811 F.2d 90 (2d Cir. 1987) (no fair use by biographer of unpublished letters).

11210 US at 430. Accord Genentech v. Eli Lilly \& Co., 998 F.2d 931, 949 (Fed. Cir. 1993); W.L. Gore \& Assoc. v. Carlisle Corp., 529 F.2d 614, 623 (3d Cir. 1976); Bowman, Ward S. Jr. (1973), Patent and Antitrust Law: A Legal And Economic Appraisal ('the legal propriety of a basic patent monopoly has to be recognized'). 
12 See e.g. Orson, Inc. v. Miramax Film Corp., 189 F.3d 377 (3d Cir. 1999). Cf. Perfumer's Workshop v. Roure Bertrand du Pont, Inc., 737 F. Supp. 785, 790-91 (SDNY 1990) (ownership and enforcement of trade secrets does not violate the antitrust laws).

13 We distinguish cases in which the intellectual property statute itself creates a compulsory licensing scheme. See e.g. 17 USC $\S \S 111$ (cable retransmissions), 112(e) (digital music sound recordings), 115 (cover license for musical compositions), 116 (jukeboxes), 118 (public broadcasting), 119 (satellite broadcast retransmissions). In those cases, an intellectual property owner's remedies are of course limited to the specified monetary remedy. But the limit arises by operation of intellectual property law, and applies whether or not the intellectual property owner itself makes use of the right.

1469 F.2d 577 ( $7^{\text {th }}$ Cir. 1934).

15 Id.; Foster v. American Mach. \& Foundry Co., 492 F.2d 1317 (2d Cir. 1974) (upholding what amounted to a compulsory license: a reasonable royalty damage award but no injunction.). See also Vitamin Technologists v. Wisconsin Alumni Research Foundation, 146 F.2d 941, 946-47, 956 ( $9^{\text {th }}$ Cir. 1945). In that case, the patentee refused to license a process for enriching margarine with vitamin $\mathrm{D}$ to manufacturers of margarine. The court held the refusal to license to be patent misuse in the circumstances, and so denied any relief, legal or equitable.

16 See Campbell v. Acuff-Rose Music Co., 510 US 569, 578 n.10 (1994) ('courts may also wish to bear in mind that the goals of the copyright law, "to stimulate the creation and publication of edifying matter", are not always best served by automatically granting injunctive relief when parodists are found to have gone beyond the bounds of fair use.') Abend v. MCA, Inc., 863 F.2d 1465, 1479 ( $9^{\text {th }}$ Cir. 1988) (finding 'special circumstances' that would cause 'great injustice' to defendants and 'public injury' were injunction to issue).

17 See Hartford-Empire Co. v. United States, 323 US 386, 432-33 (1945) ('a patent owner is not in the position of a quasi-trustee for the public'; it 'has no obligation either to use it or grant its use to others'.). We emphasize that we consider in this chapter only claims that a law-abiding intellectual property owner can be made to license its rights. The fact that antitrust law does not itself compel licensing does not preclude the use of a compulsory licensing scheme as a remedy for other sorts of antitrust violations. Indeed, HartfordEmpire itself imposed such an antitrust remedy.

18 For a discussion of concerted refusals to deal, which are treated under Section 1 of the Sherman Act, see Chapter 35 of IP and Antitrust (supra Note 1).

19 Brown Shoe Co. v. United States, 370 US 294, 320 (1962).

20797 F.2d $370\left(7^{\text {th }}\right.$ Cir. 1986).

21 Id. at 375.

22 Aspen Skiing Co. v. Aspen Highlands Skiing Corp., 472 US 585 (1985). We discuss these cases in more detail in Section III.E.

$23 \quad 797$ F.2d at 375

24830 F.2d $606\left(6^{\text {th }}\right.$ Cir. 1986).

25 Id. at 609

26 The Antitrust Division's Intellectual Property Guidelines take the position that licensing is essentially procompetitive:

Intellectual property typically is one component among many in a production process and derives value from its combination with complementary factors. Complementary factors of production include manufacturing and distribution facilities, workforces, and other items of intellectual property. The owner of intellectual property has to arrange for its combination with other necessary factors to realize its commercial value. Often, the owner finds it most efficient to contract with others for these factors, to sell rights to the intellectual property, or to enter into a joint venture arrangement for its development, rather than supplying these complementary factors itself.

Licensing, cross-licensing, or otherwise transferring intellectual property (hereinafter 'licensing') can facilitate integration of the licensed property with complementary 
factors of production. This integration can lead to more efficient exploitation of the intellectual property, benefiting consumers through the reduction of costs and the introduction of new products. Such arrangements increase the value of intellectual property to consumers and to the developers of the technology. By potentially increasing the expected returns from intellectual property, licensing also can increase the incentive for its creation and thus promote greater investment in research and development.

United States Department of Justice and Federal Trade Commission, Antitrust Guidelines for the Licensing of Intellectual Property $\$ 2.3$.

27 Cf. Genentech, Inc. v. Eli Lilly \& Co., 998 F.2d 931, 949 (Fed. Cir. 1993) (patentees must have the power to select exclusive licenses as they see fit).

28 Miller Insituform, 830 F.2d at 609.

29 See Sections III.C to III.E.

30 See Section IV.B.1 below. See also Chapter 11 of IP and Antitrust (supra, Note 1).

31 This argument is developed in Areeda, Philip and Herbert Hovenkamp, Antitrust Law (2d ed.), vol. 3 , $\uparrow 708 \mathrm{~d}$

32 A further complication is that unlike patents, trade secrets and in some cases copyrights can be kept secret from the world. Requiring licensing of these intellectual property rights would require someone to know of their existence.

33 For example, suppose that a royalty of $\$ 10$ is set by a court for a patent on a component of a product that costs $\$ 500$. Over the next several years, the price of the product drops to $\$ 25$. The royalty now seems exorbitant, and licensees will doubtless want relief from the original royalty.

34 We discuss concerted conduct and conditional licenses in detail in IP and Antitrust (supra Note 1). See generally Chapters $20-36$ in that treatise.

35 See e.g. Corsearch v. Thomson \& Thomson, 792 F. Supp. 305 (SDNY 1992) (questioning whether terminating a license of a copyrighted database to a competitor could be anticompetitive, but not addressing the issue because it found no monopoly power).

36 Commentators have argued, for instance, that price discrimination has such procompetitive justifications, and indeed that it may not be evidence of the existence of market power at all. See Klein, Benjamin and John Shepard Wiley Jr. (2003), 'Competitive Price Discrimination as an Antitrust Justification for Intellectual Property Refusals to Deal', Antitrust L.J., 70 (3), 599 (arguing that price discrimination is procompetitive and does not tend to show market power); Baker, Jonathan B. (2003), 'Competitive Price Discrimination: The Exercise of Market Power Without Anticompetitive Effects', Antitrust L.J., 70 (3), 643 (arguing that price discrimination does show market power, but not necessarily anticompetitive effect). To the extent that these arguments are correct, a desire by an intellectual property owner to price discriminate may serve to justify a unilateral but conditional refusal to deal.

37 We deal with such claims in detail in IP and Antitrust (supra Note 1), Chapter 11.

38 For good discussions of essential facilities in the intellectual property context, see Donahey, Teague I. (1997), 'Terminal Railroad Revisited: Using the Essential Facilities Doctrine to Ensure Accessibility to Internet Software Standards', AIPLA Q.J., 25, 277 Lipsky, Abbott B. Hr. and J. Gregory Sidak (1999), 'Essential Facilities', Stan. L. Rev., 51, 1187, at pp. 1218-20 (1999); McGowan, David (1996), 'Regulating Competition in the Information Age: Computer Software as an Essential Facility Under the Sherman Act', Hastings Comm/Ent. L.J., 18, 771.

39 The monopolist in an essential facilities case may be thought to have 'acted' in some sense, by refusing to deal or to continue dealing with a competitor. But generally speaking a unilateral refusal to deal is not the sort of affirmative anticompetitive conduct that the antitrust law is concerned with.

$40 \quad$ United States v. Terminal R.R. Assn., 224 US 383 (1912).

41 Otter Tail Power Co. v. United States, 410 US 366 (1973).

42 MCI Comm. Corp. v. AT\&T, 708 F.2d 1081 ( $7^{\text {th }}$ Cir. 1983). 
43 A very different sort of essential-facility-type claim is envisioned by those few cases that impose a duty to continue dealing. For example, in Aspen Skiing Co. v. Aspen Highlands Skiing Corp., 472 US 585 (1985), the Court held that a ski company that owned 3 of the 4 mountains in a local area was obligated to continue offering a multi-area skiing pass with its sole competitor in that local area. While the Court did not discuss the case in essential facilities terms, there is no other antitrust concept that readily fits these circumstances. By avoiding the use of essential facilities language, however, the Court short-circuited inquiry into how important the multi-area pass actually was to competition.

$44 \quad M C I, 708$ F.2d at 1132-33.

45 See Alaska Airlines v. United Airlines, 948 F.2d 536, 544-46 (9 ${ }^{\text {th }}$ Cir. 1991) (airline computer reservation system was not an essential facility because airlines could compete without it, albeit at higher cost).

46 Whether this defense would extend to other sorts of business justifications for refusing to deal is not clear.

47 It is not clear that Terminal Railroad fits easily in this framework, but that case may be complicated by its reliance on a conspiracy between different railroads in violation of Section 1.

48 Verizon Communications v. Law Offices of Curtis V. Trinko, 540 US 398 (2004).

49 See e.g. Areeda, Philip (1989), 'Essential Facilities: An Epithet in Need of Limiting Principles', Antitrust L.J., 58, 841; Hovenkamp, Herbert, Federal Antitrust Policy, §7.7 ('The so-called essential facility doctrine is one of the most troublesome, incoherent and unmanageable of bases for Sherman $\S 2$ liability. The antitrust world would almost certainly be a better place if it were jettisoned . . ' '); McGowan, David (1996), 'Regulating Competition in the Information Age: Computer Software as an Essential Facility Under the Sherman Act', Hastings Comm/Ent. L.J., 18, 771.

50 See Lemley, Mark A. (1996), 'Antitrust and the Internet Standardization Problem', Conn. L. Rev., 28, 1041, at pp. 1085-86.

51 The European Court of Justice did find a copyrighted television guide to be an essential facility in the Magill case, C-241/91 P (E.C.J. 1995). That decision is discussed in this book in Chapter 3 (see also Chapters 5, 8, 9).

52195 F.3d 1346 (Fed. Cir. 1999).

53 Id. at 1350. Most of those antitrust claims are based on Intel's efforts to link the two sets of intellectual property rights together. As such, they involve conditional rather than pure unilateral refusals to deal.

54 Intergraph Corp. v. Intel Corp., 3 F. Supp. 2d 1255 (N.D. Ala. 1998).

$55 \quad 195$ F.3d at $1356-1359$.

56 Id. at 1357 ('the essential facility theory is not an invitation to demand access to the property or privileges of another, on pain of antitrust penalties and compulsion; thus the courts have required anticompetitive action by a monopolist that is intended to "eliminate competition in the downstream market".').

57 Id. ('A non-competitor's asserted need for a manufacturer's business information does not convert the withholding of that information into an antitrust violation'.). Cf. Multivideo Labs v. Intel Corp., 2000 WL 502866 (SDNY 27 April 2000) (monopoly leveraging claim fails where the parties are not competitors).

The court was arguably incorrect to conclude that the parties were not in the same market. While Intergraph sold its products in a market downstream from Intel's, Intergraph's intellectual property rights, the assertion of which triggered the dispute, were in the same technology market as Intel's primary line of business (microprocessors). The court's failure to recognize this doesn't affect the essential facilities analysis, however, because any such competition would exist in the market for the essential facility itself, not the downstream market Intel was allegedly trying to control.

58995 F. Supp. 728 (S.D. Tex. 1998).

59 Id. at 751

60 Id. at 752 . 
61 Id. at 754

62 The court did not discuss the possibility that network effects could have economic consequences for the market similar to those of natural monopolies.

63 Id. at 753

64 Id. at 755.

65 Id. at 753 .

66 Id. at $755-56$.

67719 F. Supp. 1551 (S.D. Fla. 1988); rev'd on other grounds 999 F.2d $1436\left(11^{\text {th }}\right.$ Cir 1993).

68 Id. at 1563. This conclusion was reversed on appeal.

69 Id. at 1566

$70 \quad$ Aldridge, 995 F. Supp. at 755 n.146.

71 We detail these unusual circumstances in Section III.C.3, infra.

72 For more detail, see Areeva and Hovenkamp (supra Note 31), 3A Antitrust Law 971 74,787 (arguing that the essential facilities doctrine is generally unwarranted, but that an exception may reasonably be made for public utilities).

73 Verizon Communications v. Law Offices of Curtis V. Trinko, 540 US 398 (2004)

74 See also United States v. Westinghouse Elec. Corp., 648 F.2d 642 (9 ${ }^{\text {th }}$ Cir. 1981) (government challenged a refusal to deal on the ground that Mitsubishi had become so wedded to Westinghouse technology, because of the Agreements, as to be unable to compete in the United States market.').

75 See Section II.

76 See Section II.D.

77 Whether or not our per se rule is adopted, it should be clear that courts regularly reject such claims. In addition to the cases discussed above, see Service \& Training, Inc. v. Data General Corp., 963 F.2d 680 ( $4^{\text {th }}$ Cir. 1992) ('a better mouse trap is not necessarily an essential facility'.); Sun Dun, Inc. v. Coca-Cola Co., 740 F. Supp. 381, 394 (D. Md. 1990) (trademark is not an essential facility); Hudson's Bay Co. v. American Legend Co-Op, 651 F. Supp. 819, 843 n.14 (DNJ 1986) (same).

$78 \quad 274$ F. Supp. 2d 743, 745 (D. Md. 2003).

79 No. C-3626 (FTC Nov. 14, 1995).

80 Id.

81 The Tunney Act, Pub. L. No. 93-528, 88 Stat. 1706 (1974), codified as amended at 15 USC $\S 16$ (b)-(h) (1994), requires that courts approve such settlements as being in the public interest. But the standard applied is quite lax. See United States v. Microsoft, 56 F.3d 1448 (DC Cir. 1995).

82 Indeed, this is plausibly what was at stake in BellSouth. While the district court concluded that the organization of Bell's yellow pages was copyrightable, the $11^{\text {th }}$ Circuit ultimately held otherwise.

83 Morris Communications Corp. v. PGA Tour, 364 F.3d 1288 (11 ${ }^{\text {th }}$ Cir. 2004); New York Mercantile Exchange v. Intercontinental Exchange, Inc., 2004 WL 1494383 (SDNY 30 June 2004).

84708 F.2d $1081\left(7^{\text {th }}\right.$ Cir. 1983).

85326 US 1 (1945). For a full analysis of the case, see Hovenkamp, Herb (1995), 'Exclusive Joint Ventures and Antitrust Policy', Colum. Bus. L. Rev., 1.

86 Areeda and Hovenkamp (supra Note 31) note that the case did not hold that AP must open its network to all comers, just that it couldn't discriminate against newspapers that competed with existing members (3A Antitrust Law 772b2). While this is a point of distinction from the typical essential facilities case, the nondiscrimination obligation the Court did impose is certainly outside the realm of normal antitrust rules.

87 To similar effect are Drinkwine v. Federated Publications, Inc., 780 F.2d 735 ( $9^{\text {th }}$ Cir. $1985)$ and TV Communications Network v. Turner Network Television, 964 F.2d $1022\left(10^{\text {th }}\right.$ Cir. 1992). In both cases the court rejected claims that a copyright owner controlled an essential facility - an advertising tabloid in Drinkwine and a TV network in TV 
Communications. But both cases reject the claim on the antitrust merits, for failure to prove market power, without mentioning the fact that the defendants in both cases produce copyrighted works.

One case has permitted an essential facilities theory to survive a motion to dismiss without discussing the copyrighted works that were doubtless involved in the case. In In re Evic Class Action Litig., 2002 WL 1766554 (SDNY 31 July 2002), the court held that the plaintiffs stated an antitrust claim that UPS forms and tracking software were essential facilities to third parties who sought to compete with UPS in providing 'excess value' insurance for packages shipped by UPS. The UPS forms and software in question are doubtless copyrighted, though the court makes no mention of the fact. Nonetheless, this may be a case (like $M C I$ ) in which the copyrighted works are only incidental to the control of the facility itself, particularly since copyright law does not forbid the creation of interoperable programs.

88 Of course, in such a case the plaintiff will still have to meet the extremely high standards for making out an essential facilities claim. The circumstances in which it will be able to do so are extremely rare.

89 Goldwasser v. Ameritech Corp., 222 F.3d 390, 400 ( $7^{\text {th }}$ Cir. 2000)

90 Id.; see also Law Offices of Curtis V. Trinko v. Bell Atlantic Corp., 123 F. Supp. 2d 738 (SDNY 2000)

91 See Section III.C.2.

92540 US $398(2004)$.

93 For good discussions of refusals to license intellectual property as antitrust violations, see e.g. Donahey, Teague I. (2000), 'At the Intersection of Antitrust and Intellectual Property: Lessons from Intergraph v. Intel and CSU v. Xerox', Fed. Cir. Bar J., 10, 129; Hayter, Dana W. (1996), 'When a License is Worse than a Refusal: A Comparative Competitive Effects Standard to Judge Restrictions in Intellectual Property Licenses', Berkeley Tech. L.J., 11, 281; Kaufmann, Michael H. (1999), 'Image Technical Services, Inc. v. Eastman Kodak Co.: Taking One Step Forward and Two Steps Back in Reconciling Intellectua Property Rights and Antitrust Liability', Wake Forest L. Rev., 34, 471; Lao, Marina (1999), 'Unilateral Refusals to Sell or License Intellectual Property and the Antitrust Duty to Deal', Cornell J. L. \& Pub. Pol'y, 9, 193; McGowan, David (1999), 'Networks and Intention in Antitrust and Intellectual Property', J. Corp. L., 24, 485; Vermut, Richard S. (1997), 'A Synthesis of the Intellectual Property and Antitrust Laws: A Look at Refusals to License Computer Software', Colum.-VLA J. L. \& Arts, 22, 27.

94 See Section II.C.

95 For a general discussion, see Antitrust Law (supra Note 31), 3A, 9770.

96 We discuss such cases in Section III.F.

97 See e.g. Lorain Journal Co. v. United States, 342 US 143 (1951).

98 See Section II.

99 See e.g. Abbott Labs. v. Brennan, 952 F.2d 1346, 1354 (Fed. Cir. 1991) (market power conferred by IP rights cannot violate the antitrust laws; 'the patent right must be coupled with violations of $\S 2$ ').

100195 F.3d 1346 (Fed. Cir. 1999)

101 See Section III.C.2.

$102195 \mathrm{~F} .3 \mathrm{~d}$ at 1358 (citations omitted).

103 Id.

104 Id. at 1358-59. The court made no specific reference to Intel's patents as a factor in this decision, despite the district court's determination that Intel had used its patents to restrain trade, and that its patent rights did not immunize it from antitrust liability. See Intergraph Corp. v. Intel Corp., 3 F. Supp. 2d 1255, 1279 (N.D. Ala. 1998).

105203 F.3d 1322 (Fed. Cir. 2000) (referred to herein as Xerox). To the extent it is relevant, $\mathrm{HH}$ was consulted by the defendants in this case. 
106 Id. at 1326. Curiously, for this proposition the court quoted Image Technical Servs. v. Eastman Kodak Co., 125 F.3d 1195 ( $9^{\text {th }}$ Cir. 1997), discussed below, which is itself the one case that arguably does impose such liability.

107 Id. at 1327 (emphasis in original). See also Atari Games Corp. v. Nintendo of Am., 897 F.2d 1572, 1576 (Fed. Cir. 1990) (extending patent rights beyond the scope of the grant violates the antitrust laws).

108 Id. at 1328.

109 Id. at 1327.

110 See Miller Insituform Inc. v. Insituform of North Am., 830 F.2d 606, 609 (6 ${ }^{\text {th }}$ Cir. 1987) ('A patent hold who lawfully acquires a patent cannot be held liable under Section 2 of the Sherman Act for maintaining the monopoly power he lawfully acquired by refusing to license the patent to others.'); SCM Corp. v. Xerox Corp., 645 F.2d 1195, 1206 (2d Cir. 1981) ('where a patent has been lawfully acquired, subsequent conduct permissible under the patent laws cannot trigger any liability under the antitrust laws.').

111203 F.3d at 1328-29.

11236 F.3d $1147\left(1^{\text {st }}\right.$ Cir. 1994).

113 Id. at 1184.

114 Id. at 1185-86. See also Rural Tel. Serv. Co. v. Feist Publications, Inc., 957 F.2d 765, 767-69 (evaluating the reasonableness of a copyright owner's refusal to license telephone white pages).

115 Id. at 1187. The court continued in a footnote: 'Wary of undermining the Sherman Act, however, we do not hold that an antitrust plaintiff can never rebut this presumption, for there may be rare cases in which imposing antitrust liability is unlikely to frustrate the objectives of the Copyright Act.' Id. n.64.

To similar effect is Corsearch v. Thomson \& Thomson, 792 F. Supp. 305, 323 (SDNY 1992) (noting in dictum that the enforcement of a copyright was a presumptively valid business justification for a refusal to license).

116 Id. at $1188-89$

117 Xerox, 203 F.3d at 1329. Curiously, an earlier $9^{\text {th }}$ Circuit case had held with little discussion that a computer hardware manufacturer that owned a copyright in maintenance software was free to refuse to provide that software to ISOs, a result that suggests an even stronger presumption than Data General's. See Triad Sys. Corp. v. Southeastern Express Co., 64 F.3d 1330 ( $9^{\text {th }}$ Cir. 1995); see also Advanced Computer Service v. MAI Sys. Corp. 845 F. Supp. 356 (E.D. Va. 1994) (same).

118125 F.3d $1195\left(9^{\text {th }}\right.$ Cir. 1997). To the extent it is relevant, HH was consulted by the defendants in this case.

119 Kodak v. Image Technical Servs., 504 US 451 (1992).

$120 \quad 125$ F.3d at 1220.

121 Id. at 1215 .

122 Id. at 1216.

123 Id. at $1216-17$.

124 Id. at 1218.

125 The district court did not consider this issue at all, and did not give any instruction to the jury regarding a presumption based on ownership of intellectual property rights. While the Ninth Circuit held that the district court erred in failing to give such an instruction, it found that the court's error was harmless because the facts of the case rebutted the presumption. Id. at $1218-19$.

126 The evidence of this is pretty clear; Kodak's own employees testified that intellectual property rights had nothing to do with their decision to cut off the ISOs. Id. at 1219-20. We discuss the relevance of this evidence in Section III.D.4.a.

127 Id. at 1219

128 Id. at 1217.

129 One court that recognized the rather stark change in the law wrought by Xerox is Telecomm Technical Services, Inc. v. Siemens Rolm Comms., Inc., 150 F. Supp. 2d 1365, 
1368-69 (N.D. Ga. 2000). That court reversed its prior decision, concluding that after Xerox independent service organizations could not bring an antitrust claim based on an effort to leverage power from the parts market into the service market. Ironically, while the Telecomm court rendered its decision based on its belief that Federal Circuit law was controlling, on appeal the Federal Circuit ordered the case transferred to the Eleventh Circuit because of the Supreme Court's intervening decision in Holmes v. Vornado, 535 US 826 (2002). Telecomm Technical Services, Inc. v. Siemens Rolm Comms., Inc., 295 F.3d 1249 (Fed. Cir. 2002).

130 In light of the different opinions, antitrust defendants may be expected to file paten infringement claims wherever possible in order to vest jurisdiction in the Federal Circuit, with its more lenient rules. While the Federal Circuit is likely to hear most of the patentrelated antitrust cases in the future, and has asserted authority over the antitrust rules to be applied in such cases, that does not ameliorate the conflict problem. First, there is a clear conflict between the circuits in their treatment of copyright issues. Second, not all patent issues will be appealed to the Federal Circuit, both because some antitrust cases (like Image Technical) do not involve patent infringement claims by either side, and because in an important subset of patent-antitrust cases - those brought by federal or state agencies the case will not involve direct patent issues and will not be appealed to the Federal Circuit.

$131 \quad 203$ F.3d at 1324.

132 See Section III.D.3.

133 See e.g. Olympia Equip. Leasing v. Western Union Telegraph, 797 F.2d $370\left(7^{\text {th }}\right.$ Cir 1986).

134 It is not clear why this is. Image Technical originally involved both tying and monopolization claims, but only the monopolization claim went to the jury.

$135 \quad 203$ F.3d at 1327.

136 As noted above, the Federal Circuit in Xerox adopted the First Circuit approach for copyrights. 203 F.3d at 1328-29.

137 By referring to these costs, we intend to encompass not only the increased costs of litigation, but any reduction in innovation incentive attributable to the more uncertain status of intellectual property rights.

138 See in particular Sections III.E to III.G

139472 US 585 (1985). The case is discussed in much more detail in Antitrust Law (supra Note 31), 3A, $1772 \mathrm{c}$.

$140 \quad 472$ US at 585

141 Id. at 601.

142 Id. at $602-03$.

143 Cf. Hovenkamp, Herbert (2000), 'The Monopolization Offense', Ohio St. L.J., 61, 1035, at pp. 1044-45 (Aspen is 'problematic to say the least').

144 Verizon Communications v. Law Offices of Curtis V. Trinko, 540 US 398 (2004)

145 See SmileCare Dental Group v. Delta Dental Plan, 88 F.3d 780 ( $9^{\text {th }}$ Cir. 1996) (limiting Aspen to continuations of existing ventures). Cf. Antitrust Law (supra Note 31), 3A, $772 \mathrm{c} 3$ ('We would at the very least restrict Aspen to circumstances where the defendant terminated an existing joint venture without justification ...').

146504 US 451 (1992).

147 As noted above, on remand Kodak did ultimately assert patents and copyrights.

$148 \quad 36$ F.3d at 1188 .

149 United States Department of Justice and Federal Trade Commission, Antitrust Guidelines for the Licensing of Intellectual Property, § 2.3.

150 On the importance of the focus on the scope of intellectual property rights, see generally Bowman, Ward S. Jr. (1973), Patent and Antitrust Law: A Legal And Economic Appraisal; Barton, John H. (1997), 'Patents and Antitrust: A Rethinking in Light of Patent Breadth and Sequential Innovation', Antitrust L.J., 65, 449. 
151 Xerox, Kodak, and Data General all involved patents or copyrights. One court has held that the irrebuttable Xerox presumption that a unilateral refusal to deal cannot be unlawful does not extend to trade secrets. Telecomm Technical Services, Inc. v. Siemens Rolm Comms., Inc., 150 F. Supp. 2d 1365, 1370 (N.D. Ga. 2000). While the court was concerned that the broad range of protectable trade secrets would mean that 'virtually every anticompetitive refusal to deal would be beyond reach of antitrust law', we are not convinced that trade secrets should be treated differently than other forms of intellectual property. Indeed, there are good reasons to permit trade secret owners (and trademark owners, though no court has addressed it) to refuse to license their rights, since the continued existence of both trade secret and trademark rights will depend in part on how licensees behave.

The key to avoiding too broad a rule is to determine whether the power exercised is within the legitimate scope of the intellectual property right. While entitlement to trade secret protection is broad, that protection is significantly less powerful than patent protection, limiting the effect of permitting unilateral refusals to deal in trade secrets.

152 A separate question is presented when intellectual property enforcement litigation is itself claimed to violate the antitrust laws. The filing of a lawsuit triggers Noerr-Pennington immunity in most circumstances. (See Chapter 11 of IP and Antitrust, supra Note 1.) In this case, however, we deal only with antitrust liability based on refusal to license or provide access to information.

153 To the extent it is relevant, $\mathrm{HH}$ and ML were both consultants for the federal government on this case.

1541998 WL 614485 (DDC Sept. 14, 1998)

155 Id. at *15 (some citations omitted).

156 United States v. Microsoft, 87 F. Supp. 2d 30, 40 (DDC 2000).

157 The court also discussed Microsoft's intent in imposing the restrictions. Properly read, we think the court's discussion of intent is relevant only to the underlying Section 2 claim, and not to whether the intellectual property presumption has been rebutted. There is no indication in the opinion that the court intended to take sides in the Image Technical-Xerox debate discussed above.

158 Such efforts are quite common, particularly in the software industry. Software vendors regularly include terms in their licenses purporting to bind licensees to rules more restrictive than those imposed by copyright law. For examples of such terms, see Lemley, Mark A. (1999), 'Beyond Preemption: The Law and Policy of Intellectual Property Licensing', Calif. L. Rev., 87, 111, at pp.124-136.

159 See e.g. Feist Pubs. v. Rural Tel. Serv., 499 US 340 (1991), Baker v. Selden, 101 US 99 (1880), 17 USC $\S 102(b)$

16017 USC $\$ 106$

16117 USC $\$ 107$

162 See e.g. 17 USC $\S 111$ (cable retransmissions), § 112(e) (digital music sound recordings), $\S 115$ (cover license for musical compositions), \& 116 (jukeboxes), $\& 118$ (public broadcasting), $\S 119$ (satellite broadcast retransmissions).

16335 USC $\$ 271(\mathrm{a})$.

164 See e.g. United States v. Univis Lens Co., 316 US 241, 249 (1942); Glass Equip. Dev. v. Besten, Inc., 174 F.3d 1337 (Fed. Cir. 1999).

165 See e.g. Boyden Power-Brake Co. v. Westinghouse, 170 US 537, 562 (1898); Scripps Clinic \& Res. Found. v. Genentech, Inc., 927 F.2d 1565 (Fed. Cir. 1991).

166 Accordingly, we think the court in Telecomm Technical Services, Inc. v. Siemens Rolm Comms., Inc., 150 F. Supp. 2d 1365, 1369 (N.D. Ga. 2000) read Xerox too broadly. The court concluded that under Xerox a patent on parts necessarily included within its scope the right to control service using those parts. This is not correct as a matter of patent law, where the scope of a patent depends on its particular claims. The preferable approach is to ask whether a restrictive license imposed a condition outside the scope of the particular patent. If so, Xerox should not apply. 
167 See e.g. Hartford-Empire Co. v. United States, 323 US 386, 432-33 (1945); Scherer, F. M (1977), 'The Economic Effects of Compulsory Patent Licensing', in Monograph Series in Finance and Economics, at p. 47 (N.Y.U. Graduate Sch. Bus. Admin. Center for Study Fin. Inst. Monograph 1977-2, 1977) (documenting cases of compulsory licensing as an antitrust remedy).

168 Thus, in United States v. Microsoft, it is important to distinguish between the government's claims that Microsoft violated the antitrust laws by refusing to allow modifications to Windows 98 and the government's request for compelled disclosure of source code or applications program interfaces as an antitrust remedy. The former is within the scope of this chapter, and is discussed in Section III.E; the latter is outside the scope of this chapter.

169 We discuss those issues in more detail in Chapter 6 of IP and Antitrust (supra Note 1).

170 For a general discussion of this distinction, see 6 Antitrust Law (supra Note 31), vol. 6, 1 1402.

171 See Zenith Radio Corp. v. Hazeltine Res., 395 US 100, 135 (1969) (concerted refusal to license patents was illegal, even if unilateral refusals would not have been).

172 In our treatise (supra Note 1), we discuss tying arrangements in Chapters 21-22, patent pools and cross-licenses in Chapters 31, 33 and 34, grantback clauses in Chapter 25, and field of use restrictions in Chapter 24.

173203 F.3d at 1325.

174 Id. at 1327.

175 See, e.g., Image Technical, 125 F.3d at 1218 (discussing unilateral refusals to license).

176 We discuss Walker Process and sham litigation in detail in Chapter 11 of IP and Antitrust (supra Note 1).

177203 F.3d at 1327 (emphasis in original); see also Atari Games Corp. v. Nintendo of Am., 897 F.2d 1572, 1576 (Fed. Cir. 1990) ('a patent owner may not take the property right granted by a patent and use it to extend his power in the marketplace improperly, i.e. beyond the limits of what Congress intended to give in the patent laws.').

$178 \quad 203$ F.3d at 1327.

179 2000-1 Trade Cas. $\$ 72,890$ (N.D. Cal. 2000).

180 We agree with David McGowan's reading of the situation:

The Federal Circuit's recent [Xerox] decision ... is best read as affirming the distinction between simple and conditional refusals. ... [T] he exception the Federal Circuit explicitly recognized for tying arrangements includes conditional agreements that have the same possible economic effects - extending the economic power of a patent beyond the scope of the patent grant.

David McGowan (2001), 'Innovation, Uncertainty, and Stability in Antitrust Law', Berkeley Tech. L.J., 16 (2), 729-811 (also noting that a reading limited to tying cases 'would make little economic sense').

181 Eastman Kodak v. Image Technical Servs., 504 US 451, 480 n.29 (1992). The Court has drawn the same line in the copyright context. See United States v. Loew's, 371 US 38, 47 48 (1962).

182 A somewhat broader statement of the conditional refusal - unilateral conduct distinction is United States v. Westinghouse Elec. Corp., 648 F.2d 642, 647 ( $9^{\text {th }}$ Cir. 1981). There, the court drew a distinction between acts which expand the patent monopoly and those which merely enforce a patent right within its lawful scope. As examples of the former, the court cited tying arrangements, block-booking agreements, price-restricted patent pools, and acquisition of patents from third parties.

18315 USC $\S 14$.

184 See International Salt Co. v. United States, 332 US 392 (1947); see IP and Antitrust, (supra Note 1) Chapter 21 (discussing tying arrangements).

185 For an extensive discussion of this issue in the law of tying, see Antitrust Law, vol. 10, $9 \uparrow$ $1752-1757$.

186 For a much more detailed discussion of this issue, see Antitrust Law, vol. 7, qศ 1439-1458. 
187 See, e.g. United States v. Colgate \& Co., 250 US 300, 307 (1919).

188 See generally Monsanto Co. v. Spray-Rite Corp., 465 US 752 (1984).

189963 F.2d 680 ( $4^{\text {th }}$ Cir. 1992).

190 Id. at 686

19115 USC $\S 14$. Because it is limited to commodities, Section 3 of the Clayton Act will apply to conditional transfers of goods embodying intellectual property, such as books, videos, and computer disks, but not to pure licenses of intellectual property rights.

192 United States v. Microsoft Corp., 253 F.3d 34, 63 (DC Cir. 2001) (en banc) (Microsoft IV).

193 Telecomm Technical Services, Inc. v. Siemens Rolm Comms., Inc., 150 F. Supp. 2d 1365, 1369 (N.D. Ga. 2000).

194 We discuss those limits in IP and Antitrust (supra Note 1), Chapters 20-36. See also United States v. Westinghouse Elec. Corp., 648 F.2d 642, 647 (9 $9^{\text {th }}$ Cir. 1981) (distinguishing between a refusal to license to some parties, which is within the scope of the patent grant, and tying or conditioning a patent license in a way that 'seeks to expand that monopoly by misuse, agreement, or accumulation').

195645 F.2d 1195 (2d Cir. 1981).

196 To trigger Section 7 of the Clayton Act, the acquisition of a patent must be from an external source. Internal development of inventions that are then patented cannot give rise to antitrust liability. See Automatic Radio Co. v. Hazeltine Res. Co., 339 US 827 (1950).

197 We discuss the legal standards for acquisition of intellectual property in Chapter 14 of IP and Antitrust (supra Note 1).

198 In re Intel Corp., Analysis of Proposed Consent Order to Aid Public Comment, FTC Dock. No. 9288 (March 1999).

199 Id.

200 Evidence that the case should be treated differently from Xerox includes the fact that the Federal Circuit decided the Intergraph case only three months before Xerox, yet clearly did not articulate anything like a per se rule of legality. See Intergraph Corp. v. Intel Corp., 195 F.3d 1346 (Fed. Cir. 1999).

201 Id.

202 For a discussion of the court's tying holding, see IP and Antitrust (supra Note 1), \$21.6.

203 For a discussion of the court's essential facilities holding, see IP and Antitrust (supra Note $1), \S 3 \mathrm{c} 2$.

204195 F.3d at 1357.

205 In re Intel Corp., Agreement Containing Consent Order §II.A-B, FTC Dock. No. 9288 (March 1999).

206 See IP and Antitrust (supra Note 1), §2c.

$207 \quad 195$ F.3d at 1356.

208 Digital Equipment Corporation, unlike Intergraph, was at the time a direct competitor of Intel through its Alpha chip, as well as a purchaser of Intel's microprocessor products.

209 This argument is similar to the competitive concerns raised by exclusive grantback clauses, and indeed Intel's alleged policy resembles a grantback clause in significant ways. Significantly, however, Intel's policy more closely resembles a non-exclusive grantback clause, which is not normally thought to be a risk to competition.

210 See IP and Antitrust (supra Note 1), chapter 34 (discussing cross-licensing arrangements and blocking patents).

211 The FTC consent decree attempted to take this concern into account. It permits Intel to cut off any buyer who sues it for patent infringement and seeks injunctive relief rather than damages. See In re Intel Corp., Agreement Containing Consent Order §II.A, FTC Dock. No. 9288 (March 1999). 